\title{
Purinergic Regulation of Endothelial Barrier Function
}

\author{
Muhammad Aslam ${ }^{1,2,3, *}$, Dursun Gündüz ${ }^{1,4}$, Christian Troidl ${ }^{1,2,3}$, Jacqueline Heger ${ }^{5}$, Christian W. Hamm ${ }^{1,2,3}$ \\ and Rainer Schulz ${ }^{5}$ (D) \\ 1 Experimental Cardiology, Department of Internal Medicine I, Justus Liebig University, Aulweg 129, \\ 35392 Giessen, Germany; Dursun.Guenduez@med.uni-giessen.de (D.G.); \\ christian.troidl@innere.med.uni-giessen.de (C.T.); christian.hamm@innere.med.uni-giessen.de (C.W.H.) \\ 2 Department of Cardiology, Kerckhoff Clinic GmbH, 61231 Bad Nauheim, Germany \\ 3 DZHK (German Centre for Cardiovascular Research), Partner Site Rhein-Main, 61231 Bad Nauheim, Germany \\ 4 Department of Cardiology and Angiology, Evangelisches Jung Stilling Krankenhaus GmbH, \\ 57074 Siegen, Germany \\ 5 Institute of Physiology, Justus Liebig University, 35392 Giessen, Germany; \\ Jacqueline.Heger@physiologie.med.uni-giessen.de (J.H.); \\ Rainer.Schulz@physiologie.med.uni-giessen.de (R.S.) \\ * Correspondence: muhammad.aslam@physiomed.jlug.de; Tel.: +49-641-99-42248
}

check for updates

Citation: Aslam, M.; Gündüz, D.; Troidl, C.; Heger, J.; Hamm, C.W.; Schulz, R. Purinergic Regulation of Endothelial Barrier Function. Int. J. Mol. Sci. 2021, 22, 1207. https:// doi.org/10.3390/ijms22031207

Received: 14 December 2020

Accepted: 22 January 2021

Published: 26 January 2021

Publisher's Note: MDPI stays neutral with regard to jurisdictional claims in published maps and institutional affiliations.

Copyright: (C) 2021 by the authors. Licensee MDPI, Basel, Switzerland. This article is an open access article distributed under the terms and conditions of the Creative Commons Attribution (CC BY) license (https:// creativecommons.org/licenses/by/ $4.0 /)$.

\begin{abstract}
Increased vascular permeability is a hallmark of several cardiovascular anomalies, including ischaemia/reperfusion injury and inflammation. During both ischaemia/reperfusion and inflammation, massive amounts of various nucleotides, particularly adenosine $5^{\prime}$-triphosphate (ATP) and adenosine, are released that can induce a plethora of signalling pathways via activation of several purinergic receptors and may affect endothelial barrier properties. The nature of the effects on endothelial barrier function may depend on the prevalence and type of purinergic receptors activated in a particular tissue. In this review, we discuss the influence of the activation of various purinergic receptors and downstream signalling pathways on vascular permeability during pathological conditions.
\end{abstract}

Keywords: Rac1; RhoA; peripheral actin; adenosine; ATP; ADP; UTP; endothelial permeability; oedema; P2X receptors; P2Y receptors

\section{Introduction}

The vascular endothelium (VE), consisting of monolayers of endothelial cells (ECs), is located at the interface between the vascular and perivascular compartments and extends over a wide surface area. The VE separates strictly two compartments and regulates the trafficking of ions, solutes, macromolecules and leukocytes across the vessel wall, thus maintaining tissue homeostasis [1,2]. Additionally, it secretes several vasoactive agents that not only maintain its integrity but also regulate platelet function and vascular smooth muscle tone, and thus actively participate in the regulation of blood pressure. The semipermeable barrier function of VE is dependent on the size of the molecules, and this size-selective nature of the barrier to plasma proteins is a key factor in establishing protein gradients, which is required for fluid balance of tissues [1,3]. The loss of this barrier function of VE results in increased vascular permeability and leakage of blood components, which may finally result in organ dysfunction and life-threatening oedema formation $[2,4]$.

Endothelial barrier integrity is maintained by the equilibrium of competing adhesive and contractile forces generated by adhesive molecules located at cell-cell and cell-matrix contacts and the acto-myosin-based contractile machinery, respectively [5]. ECs are tightly interconnected by the interaction of junctional proteins such as VE-cadherin, zona occluding 1 (ZO-1), occludins, and catenins that are linked to the actin cytoskeleton of adjacent cells [6,7]. Therefore, changes in the actin cytoskeleton dynamics and/or activation state of the EC contractile machinery may affect the stability of cell-cell junctions and barrier function. 
Two members of the Rho family of GTPases, RhoA and Rac1, are the major regulators of endothelial actin cytoskeleton dynamics and contraction and thereby play a key role in the maintenance of endothelial barrier integrity. Constitutive activation of RhoA results in the loss of basal VE-cadherin and potentiates hypoxia-reoxygenation ( $H / R)$-induced loss of endothelial barrier function, whereas suppression of RhoA activity attenuates the agonist-induced increase in endothelial permeability [8,9]. On the other hand, suppression of Rac1 activity in cultured ECs results in loss of the endothelial barrier and abolishes the recovery of EC barrier integrity following H/R-induced barrier failure. Accordingly, constitutive activation of Rac1 results in strong junctional staining of VE-cadherin and abrogates H/R-induced loss of cell-cell junctions [8].

The activation state of the endothelial contractile machinery is regulated by the phosphorylation state of regulatory myosin light chains (MLC), which are phosphorylated by MLC kinase (MLCK) [10] and dephosphorylated by MLC phosphatase (MLCP) [11]. Activation of Rho/Rho kinase (Rock) and MEK/ERK pathways induces MLC phosphorylation via inhibition of MLCP or activation of MLCK, respectively [12-14]. Thrombin inhibits MLCP by inducing the phosphorylation of its regulatory subunit MYPT1 at T850 and activates MLCK via phospholipase C/inositol tris-phosphate (PLC/IP3)-dependent release of $\mathrm{Ca}^{2+}$ from intracellular stores $[12,14,15]$. Both of these actions contribute to its endothelial barrier destabilisation properties. A schematic presentation of mechanisms regulating endothelial barrier properties is shown below (Figure 1).

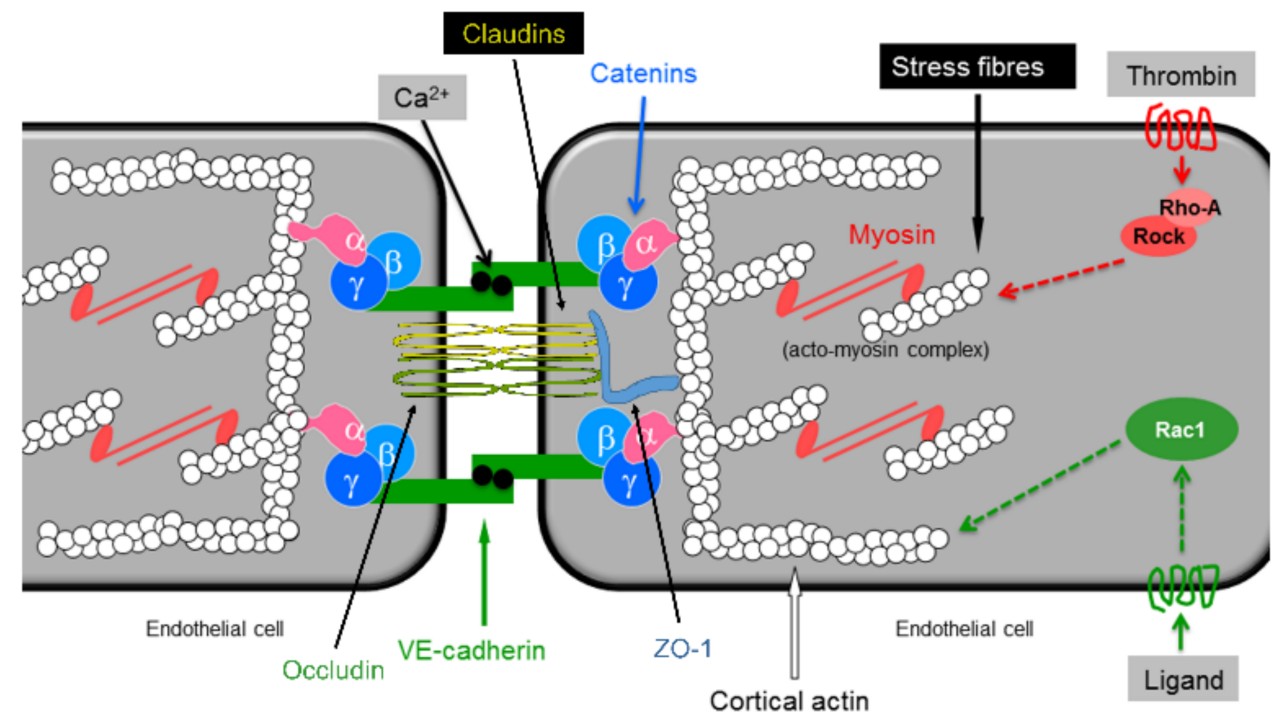

Figure 1. Schematic presentation of regulators of endothelial barrier properties. Rock: Rho associated kinase

Endothelial barrier integrity is influenced by several circulating, blood-borne hormones and agents/factors such as adenosine triphosphate (ATP) and its metabolites adenosine diphosphate (ADP) and adenosine. The major sources of vascular nucleotides are erythrocytes, platelets, and the endothelium [16]. Platelets contain nucleotides in their granules, and upon degranulation, bulk plasma levels of ATP can reach $50 \mu \mathrm{M}$ [17], with even higher local concentrations predicted at the endothelial surface [18]. The endothelium releases nucleotides in response to shear stress [19], inflammatory mediators like thrombin [20], and hypoxia [21,22]. ATP and other nucleotides either released from vascular cells or applied exogenously can act at endothelial purinoceptors and modulate the barrier function of the endothelium $[21,23,24]$. Activation of purinergic receptors also induces the release of von Willebrand Factor (vWF) from ECs [25], which via reactive oxygen species (ROS)-dependent upregulation of endothelin-1 [26] may modulate endothelial barrier function. 


\section{Purine Receptors}

There are two main classes of purine receptors: P1 receptors activated by adenosine and analogues, and $\mathrm{P} 2$ receptors recognised by purine and pyrimidine nucleotides (ATP, ADP, uridine triphosphate (UTP), uridine diphosphate (UDP)). P1 receptors are further divided into $A_{1}, A_{2}$, and $A_{3}$ subtypes, depending on their affinity for adenosine. P2 receptors are further classified into ionotropic P2X and metabotropic P2Y receptors $[27,28]$. Nineteen different human purine receptors have been identified, cloned, and characterised [29]. Nearly all of these receptors are expressed on various cells of the cardiovascular system $[27,29]$. Several types of cells, particularly ECs and platelets, actively release nucleotides such as ATP that can activate a variety of the purine receptors in the vicinity $[30,31]$. This receptor activation scheme may be further complicated by the activity of ectonucleotidases that hydrolyse ATP to adenosine, which can activate P1 receptors [32].

\section{Adenosine and Adenosine (P1) Receptors}

Physiological extracellular adenosine levels range from 20 to $300 \mathrm{nM}$, which rise to a low micromolar range during exercise and to a high micromolar level under pathological conditions like ischaemia [33,34]. Under physiological conditions, the major source of extracellular adenosine is intracellular adenosine released by nucleotide transporters; however, under stress conditions, it is generated from its precursors ATP, ADP, and adenosine monophosphate (AMP) by the combined activities of extracellular ectonucleotidases, CD73 and CD39 [35]. Extracellular adenosine mediates its effects via adenosine receptors. There are four well-characterised adenosine receptors, namely adenosine $A_{1}, A_{2 A}, A_{2 B}$, and $A_{3}$, which are classified as high $\left(\mathrm{A}_{1}, \mathrm{~A}_{2 \mathrm{~A}}, \mathrm{~A}_{3}\right)$ or low $\left(\mathrm{A}_{2 \mathrm{~B}}\right)$ affinity for binding their parent physiological agonist, adenosine [36]. All four adenosine receptors possess seven transmembrane domains and belong to the family of G-protein-coupled receptors (GPCR) [37]. The $A_{1}$ and $A_{3}$ receptors are coupled to $G_{q}$ and /or $G_{i / o}$, whereas $A_{2 A}$ and $A_{2 B}$ are coupled to $G_{s}$ proteins. Activation of $A_{1}$ and $A_{3}$ receptors results in inhibition of adenylyl cyclase (AC) activity, leading to reduction in cyclic AMP (cAMP) production and suppression of downstream signalling $[37,38]$. Their activation also leads to $\mathrm{PLC} / \mathrm{IP}_{3}$-dependent release of $\mathrm{Ca}^{2+}$ from the endoplasmic reticulum (ER), protein kinase $\mathrm{C}$ (PKC) activation, and nitric oxide (NO) production [39-42]. In cardiomyocytes and neurons, activation of $\mathrm{A}_{1}$ adenosine receptors stimulates the opening and blockade of $\mathrm{K}^{+}$channels and $\mathrm{P}$ - and $\mathrm{N}$-type $\mathrm{Ca}^{2+}$ channels, respectively $[43,44]$. Activation of both $\mathrm{A}_{1}$ and $\mathrm{A}_{3}$ receptors leads to PKC-dependent and independent mitogen-activated protein kinase (MAPK) activation [45]. Activation of both adenosine $\mathrm{A}_{2 \mathrm{~A}}$ and $\mathrm{A}_{2 \mathrm{~B}}$ receptors results in activation of $\mathrm{AC}$, enhanced cAMP production, and activation of downstream signalling [36]. Adenosine receptors are widely distributed throughout the nervous, cardiovascular, respiratory, urogenital, gastrointestinal, and immune systems. All adenosine receptors are expressed on various cells of the cardiovascular system, including ECs [37,46].

\subsection{Adenosine Receptors and the Endothelial Barrier}

Adenosine is a non-selective agonist for all adenosine receptors and produces differential effects on endothelial permeability of various vascular beds depending on the type of receptors expressed.

\subsubsection{Adenosine Receptors and Lung Microvascular Permeability}

In the lung vasculature, adenosine signalling has largely been shown to enhance endothelial barrier properties and ameliorate agonist-induced hyperpermeability. In a mouse model of acute lung injury, knockdown of CD39 or inhibition of CD73, the two sequential enzymes responsible for adenosine production, resulted in development of severe lung oedema in response to ventilation compared with wild-type littermates. These animals were rescued by the addition of exogenous apyrase, suggesting a protective role played by adenosine [47]. Both adenosine $A_{2 A}$ or $A_{2 B}$ receptors seem to mediate the protective effects of adenosine in the lung [48,49]. In an isolated rat lung perfusion model 
of ischaemia/reperfusion (IR), a selective $A_{2}$-receptor agonist reduced the IR-induced increase in microvascular permeability [50]. Pharmacological activation of adenosine $\mathrm{A}_{2 \mathrm{~A}}$ and $\mathrm{A}_{2 \mathrm{~B}}$ receptors protected against hypoxia and lipopolysaccharide (LPS)-induced development of lung oedema [51,52], whereas deletion of adenosine $A_{2 A}$ or $A_{2 B}$ receptors in mice resulted in loss of adenosine-mediated preservation of the lung microvascular endothelial barrier $[51,52]$. These protective effects are mediated via augmented production of cAMP and downstream activation of Rac1 [53]. Likewise, we have previously shown that elevation of intracellular cAMP via adrenomedullin receptor activation protects against lung oedema [54]. On the other hand, too much adenosine also seems to be detrimental for the lung vasculature. Deletion of adenosine deaminase, an enzyme responsible for adenosine degradation, resulted in severe respiratory distress and lung inflammation in mice [55]. However, deletion of $A_{2 B}$ receptors in these mice did not rescue but worsened the conditions, which were accompanied by enhanced loss of pulmonary barrier function [56], suggesting a protective role of $A_{2 B}$ receptors. In contrast to murine lungs, in feline lungs, adenosine $A_{1}$ receptor activation mediates IR- and LPS-induced pulmonary microvascular barrier disruption [57,58]: perfusion with $\mathrm{A}_{1}$ receptor antagonists xanthine amine congener (XAC)/8-cyclopentyl-1,3-dipropylxanthine (DPCPX) ameliorates IR-induced lung injury and oedema in these animals. These species differences are probably due to differential expression of adenosine receptors in murine and feline lungs. Like $A_{2}$ receptor activation, pharmacological activation of adenosine $\mathrm{A}_{3}$ receptors with a selective agonist also protects against reperfusion-induced lung oedema. This protective effect is lost in $\mathrm{A}_{3}$ knockout mice in vivo [59]. However, the mechanism of this protective effect is still elusive.

\subsubsection{Adenosine Receptors and the Blood-Brain Barrier}

The blood-brain barrier is a highly specialised structure formed by a very tight monolayer of microvascular ECs that are distinct from ECs of other vascular beds [60]. The brain ECs form tight junctions consisting of claudins, occludins, VE-cadherin, junctional adhesion molecules (JAMs), and zonula occludens (particularly ZO-1). Human and murine brain microvascular ECs express adenosine $A_{1}$ and $A_{2 A}$ receptors [61-63]. Adenosine causes an elevation of central nervous system (CNS) barrier permeability. In an elegant study, Carman et al. demonstrated that a stable adenosine analogue 5'-Nethylcarboxamidoadenosine (NECA) and selective $\mathrm{A}_{1}$ and $\mathrm{A}_{2 \mathrm{~A}}$ receptor agonists increased blood-brain barrier permeability to low-molecular-weight dextran [63]. These adenosine effects were attenuated in mice lacking either $A_{1}$ or $A_{2 A}$ receptors [63]. Similarly, mice lacking CD73 had low levels of extracellular adenosine and were protected against experimental autoimmune encephalomyelitis-induced development of brain oedema and leukocyte infiltration [64]. Accordingly, inhibition of endothelial $\mathrm{A}_{2 \mathrm{~A}}$ receptors protected mice against thromboembolic stroke-induced development of cerebral oedema and leukocyte infiltration [65]. Likewise, regadenson, a selective $\mathrm{A}_{2 \mathrm{~A}}$ receptor agonist used clinically as a coronary vasodilator for myocardial perfusion imaging, increased permeability of the human blood-brain barrier in vitro [66] and in that of the mouse in vivo [63]. It has recently been shown that certain viruses and bacteria exploit this reaction of the blood-brain barrier to adenosine to open the barrier for their entry into the brain by increasing local production of adenosine, which causes transient opening of the blood-brain barrier and allows their entry to the central nervous system (CNS) $[67,68]$. Several groups have also recently tried to exploit this property of adenosine receptor activation to transiently open the blood-brain barrier for the local delivery of drugs to the CNS [69-74].

\subsubsection{Adenosine Receptors and Coronary Microvascular Barrier}

As in the blood-brain barrier, adenosine receptor activation in the coronary microvasculature results in loss of barrier integrity. $\mathrm{A}_{2}$ receptor activation increased permeability of rat coronary microvascular ECs in vitro [75]. Infusion of adenosine in pigs on a high-fat diet resulted in increased cardiac microvascular permeability in vivo [76]. Similarly, Di Napoli et al. showed that DPCPX abrogates reperfusion-induced coronary hyperpermeability [77]. 
However, the authors used DPCPX at a concentration that blocks all adenosine receptors, suggesting $\mathrm{A}_{2}$ receptors were also antagonised. In line with these reports, we have previously demonstrated that reperfusion caused the release of ATP from isolated rat coronary microvascular ECs that was degraded to adenosine. Inhibition of either ectonucleotidases or adenosine receptors abrogated endothelial barrier failure, whereas addition of apyrase and ectonucleotidases worsened reperfusion-induced endothelial barrier failure [21]. In a follow-up study, we demonstrated that adenosine induced an increase in rat mesentery microvascular permeability in situ and cardiac oedema in vivo. These adenosine effects were blocked by adenosine receptor antagonists. Furthermore, we showed that these effects were due to cAMP-mediated disruption of the microvascular endothelial cytoskeleton [78]. In a related study, we demonstrated that adenosine induced cAMP production (via adenosine $\mathrm{A}_{2}$ receptors) in coronary microvascular ECs [79] that caused an inhibition of RhoA and Rac1 signalling [80]. This is in contrast to macrovascular ECs, where cAMP production inhibited RhoA/Rock signalling while activating Rac1 GTPase [81,82]. Inhibition of both RhoA and Rac1 results in complete breakdown of the EC cytoskeleton and disruption of cell-cell junctions $[78,80]$. Activation of Rac1 rescued these cells from the loss of endothelial barrier integrity [80].

\subsubsection{Adenosine Receptors and the Macrovascular Endothelial Barrier}

In general, adenosine receptor activation in macrovascular ECs enhances endothelial barrier properties and ameliorates the effect of barrier-disrupting agents [79,83-85]. The mechanism involves the production of cAMP via activation of $A_{2 A}$ and $A_{2 B}$ receptors by adenosine and its analogues. Enhanced cellular cAMP levels suppress the activity of the endothelial contractile machinery in a RhoA/Rock-dependent manner and activate Rac1 GTPase via protein kinase A (PKA) and exchange protein directly activated by cAMP (Epac) activation [82]. Table 1 summarises the major preclinical studies that investigated purinergic receptors in relation to endothelial barrier function, and Figure 2 summarises the key mechanisms involved in the adenosine receptors-mediated endothelial barrier regulation in various vascular beds.

Table 1. Effect of purinergic receptor activation/inhibition on endothelial barrier of various vascular beds.

\begin{tabular}{|c|c|c|c|}
\hline Receptor/Agonist & Model & Observation & Reference(s) \\
\hline Adenosine & CD39 KO mice & Lung oedema & [47] \\
\hline ATP + Apyrase & Rat heart perfusion in vivo & Increased oedema & [78] \\
\hline $\mathrm{A}_{1}$ antagonist & Feline lung (IR) in vivo & Reduced lung oedema & {$[57,58]$} \\
\hline $\begin{array}{l}\mathrm{A}_{1} \text { and } \mathrm{A}_{2 \mathrm{~A}} \mathrm{KOs}_{1} \text { and } \mathrm{A}_{2 \mathrm{~A}} \\
\text { agonists }\end{array}$ & Mouse BBB in vivo & $\begin{array}{l}\mathrm{A}_{1} / \mathrm{A}_{2 \mathrm{~A}} \text { agonists induced } \mathrm{BBB} \\
\text { permeability, effects lost in KOs }\end{array}$ & {$[63,66]$} \\
\hline $\begin{array}{l}\text { FDA approved } A_{2 A} \text { agonist } \\
\text { regadenoson }\end{array}$ & Rat model of brain drug deli-very & Increased BBB permeability of test drugs & {$[69,70,72,73]$} \\
\hline $\mathrm{A}_{2 \mathrm{~A}}$ agonist & Isolated pig lungs (IR) & Reduced lung oedema & [48] \\
\hline $\mathrm{A}_{2 \mathrm{~A}} \mathrm{KO} / \mathrm{A}_{2 \mathrm{~A}}$ agonist & Lung permeability in vivo & $\begin{array}{l}\mathrm{A}_{2 \mathrm{~A}} \text { agonist reduced lung } \\
\text { permeability/Effect lost in } \mathrm{A}_{2 \mathrm{~A}} \mathrm{KO}\end{array}$ & [51] \\
\hline $\mathrm{A}_{2 \mathrm{~B}} \mathrm{KO}$ & Ventilator-induced lung injury & Increased lung oedema & [49] \\
\hline $\mathrm{A}_{3} \mathrm{KO} / \mathrm{A}_{3}$ agonist perfusion & Lung IR (oedema) in vivo & $\begin{array}{l}\mathrm{A}_{3} \text { agonist reduced lung oedema/Effect } \\
\text { lost in } \mathrm{A}_{3} \mathrm{KO}\end{array}$ & [86] \\
\hline P2X4 antagonist & $\begin{array}{l}\text { Brain middle artery occlusion } \\
\text { (IPC-IR) mouse model }\end{array}$ & $\begin{array}{l}\text { P2X } 4 \text { antagonist abrogates protective } \\
\text { effects of IPC }\end{array}$ & [87] \\
\hline P2X7 antagonists & $\begin{array}{l}\text { Rat intracranial } \\
\text { haemorrhage/oedema }\end{array}$ & $\begin{array}{l}\text { P2X7 antagonists alleviate oedema } \\
\text { deve-lopment }\end{array}$ & [88] \\
\hline $\mathrm{P} 2 \mathrm{X7} \mathrm{KO}$ & Mouse traumatic brain injury & Reduced oedema development in KOs & [89] \\
\hline $\mathrm{P} 2 \mathrm{X7} \mathrm{KO}$ & $\begin{array}{l}\text { Mouse middle cerebral artery } \\
\text { occlusion }\end{array}$ & Aggravated oedema development in KOs & [90] \\
\hline $\mathrm{P}_{2} \mathrm{Y}_{1} / \mathrm{apoE}$ double $\mathrm{KO}$ & Atherosclerosis & $\begin{array}{l}\text { Reduced atherosclerotic plaques in } \\
\text { double KOs }\end{array}$ & [91] \\
\hline $\mathrm{P}_{2} \mathrm{Y}_{1}$ agonist & Mouse traumatic brain injury & $\begin{array}{l}\mathrm{P}_{2} \mathrm{Y}_{1} \text { agonist ameliorates oedema } \\
\text { development }\end{array}$ & [92] \\
\hline
\end{tabular}


Table 1. Cont.

\begin{tabular}{|c|c|c|c|}
\hline Receptor/Agonist & Model & Observation & Reference(s) \\
\hline $\begin{array}{l}\text { EC-specific } \mathrm{P}_{2} \mathrm{Y}_{2} / \mathrm{apoE} \\
\text { double } \mathrm{KO}\end{array}$ & Atherosclerosis & $\begin{array}{l}\text { Development of stable plaques in double } \\
\text { KOs }\end{array}$ & [93] \\
\hline $\mathrm{P}_{2} \mathrm{Y}_{4} \mathrm{KO}$ & Myocardial infarction & $\begin{array}{l}\text { Protection against myocardial infarction } \\
\text { injury }\end{array}$ & [94] \\
\hline $\mathrm{P}_{2} \mathrm{Y}_{6} / \mathrm{apoE}$ double $\mathrm{KO}$ & Atherosclerosis & $\begin{array}{l}\text { Double KOs develop smaller and less } \\
\text { inflamed lesions }\end{array}$ & [95] \\
\hline $\mathrm{P}_{2} \mathrm{Y}_{12}$ antagonist & In vitro endothelial barrier model & $\begin{array}{l}\mathrm{P}^{2} \mathrm{Y}_{12} \text { antagonist ameliorates } \\
\text { thrombin-induced hyperpermeability }\end{array}$ & [84] \\
\hline
\end{tabular}

ATP: adenosine 5'-triphosphate; BBB: Blood-brain barrier; EC: endothelial cell; FDA: United-States food and drug administration; IR: Ischaemia reperfusion; IPC: Ischaemic pre-conditioning; KO: Knockout.

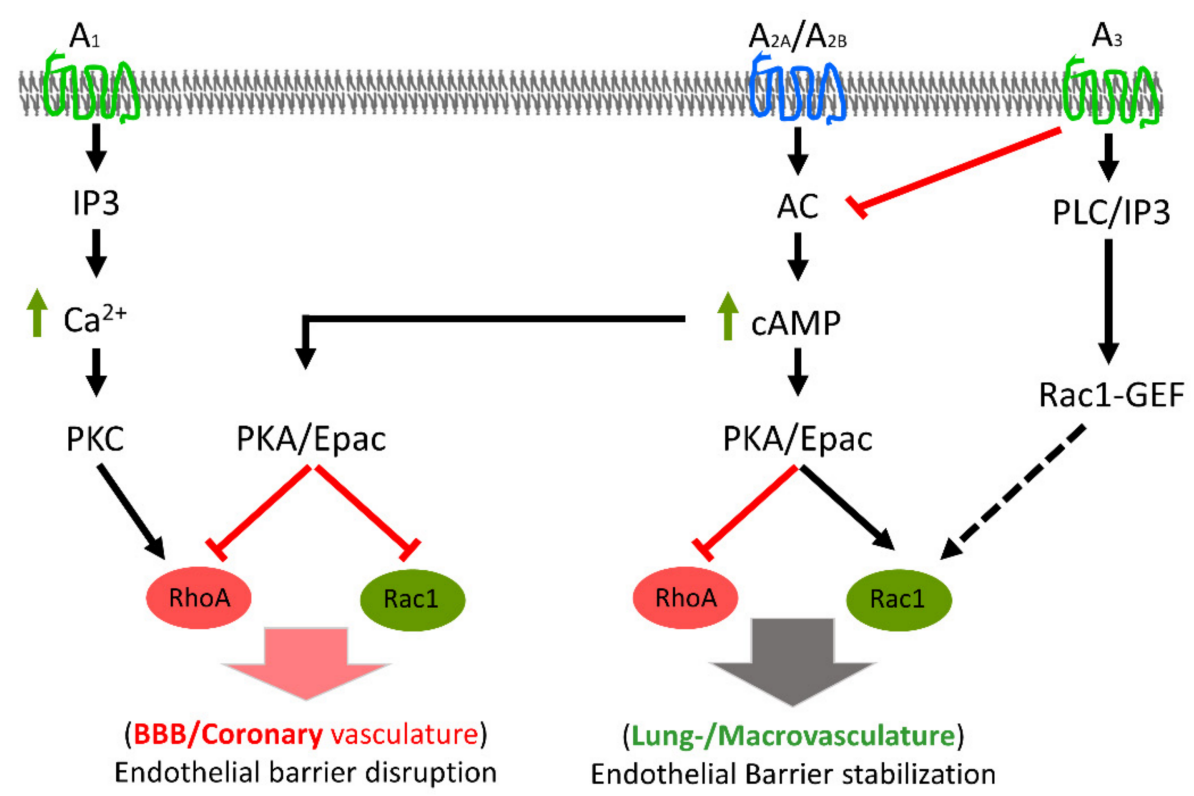

Figure 2. Key mechanisms involved in adenosine receptors-mediated endothelial barrier regulation. In lung microvasculature and macrovascular endothelium, $\mathrm{A}_{2}$ receptor activation causes an activation of Rac1 and an inhibition of RhoA, leading to stabilisation of the endothelial barrier. On the other hand, in coronary microvascular ECs, inhibition of both RhoA and Rac1 results in disruption of endothelial cytoskeleton and barrier failure. Black arrows indicate sequence of signal transduction, broken arrow indicates involvement of multiple steps in between, and green arrows indicate increase in cellular levels of indicated second messenger. Red bocks mean inhibition. AC: adenylyl cyclase; cAMP: cyclic adenosine monophosphate; GEF: guanine exchange factor; IP3: inositol triphosphate; PKA: protein kinase A; PKC: protein kinase C; PLC: phospholipase C.

\section{P2X Receptors and Signalling}

The family of P2X receptors are non-selective ion channels comprising one or more of seven monomeric proteins (P2X1-P2X7). Each monomeric P2X protein consists of two transmembrane domains (TM1 and TM2) linked via an extracellular ligand-binding loop. The monomeric P2X proteins combine to form trimeric homomultimeric or heteromultimeric ion pores [96-99]; thus, each P2X receptor complex contains three ATP binding sites. At least 13 different trimeric combinations (P2X1, P2X2, P2X3, P2X4, P2X5, P2X7, $\mathrm{P} 2 \mathrm{X} 1 / 2, \mathrm{P} 2 \mathrm{X} 1 / 4, \mathrm{P} 2 \mathrm{X} 1 / 5, \mathrm{P} 2 \mathrm{X} 2 / 3, \mathrm{P} 2 \mathrm{X} 2 / 5, \mathrm{P} 2 \mathrm{X} 2 / 6$, and P2X4/6) have been reported and functionally characterised in vitro and partly in vivo $[28,99]$. Of note, P2X6 exists only in heteromeric combinations. Binding of ATP to the extracellular ligand-binding domain induces conformational changes in the multimeric ion pore, leading to opening of the pore and allowing the passage of ions into the cell. P2X receptors are generally known as non-selective cation channels, mainly permeable to $\mathrm{Na}^{+}, \mathrm{K}^{+}$, and $\mathrm{Ca}^{2+}$ under physiological 
conditions, although a recombinant $\mathrm{P} 2 \mathrm{X} 5$ receptor has been shown to allow the passage of $\mathrm{Cl}^{-}$. Excitable cells are thus depolarised upon activation of P2X receptors. Moreover, increased intracellular $\mathrm{Ca}^{2+}$ levels initiate a diverse array of $\mathrm{Ca}^{2+}$-dependent signalling pathways, both in excitable and non-excitable cells, that regulate various cellular processes, including cell migration, proliferation, necrosis, and apoptosis.

\section{P2X Receptors and Endothelial Barrier}

P2X receptors are widely expressed throughout the cardiovascular system. mRNA and protein of all P2X receptors have been detected in the endothelium of various types of blood vessels [100-107], but-with the possible exceptions of P2X4 and to some extent P2X7-their roles are unclear $[100,103,108]$. Human venous endothelium expresses higher levels of P2X4 than arterial endothelium [109]. The most studied human primary ECs are umbilical vein ECs (HUVECs), which express primarily P2X4 and P2X7 and low levels of P2X6 receptors [107] (unpublished data). P2X4 receptors mediate shear stress-induced $\mathrm{Ca}^{2+}$ currents in endothelium [110] that may be responsible for shear stress-mediated endothelial NO production and vasodilation [111]. The vessels from P2X4 $4^{(-/-)}$mice do not show an EC response to flow, such as calcium influx and subsequent production of NO [112]. A loss-of-function mutation in the human P2X4 receptor is associated with increased pulse pressure [113]. Cardiac ectopic expression of the P2X4 receptor was protective in a mouse model of heart failure [114]. Accordingly, the P2X4 receptor was the major regulator of ischemic preconditioning-mediated neuroprotection [87]. In HUVECs, the P2X4 receptor associates with VE-cadherin and may be involved in the regulation of cell-cell junctions [100]. In this context, we observed that ivermectin, a positive modulator of the P2X4 receptor, attenuated thrombin-induced HUVEC monolayer hyperpermeability (Figure 3). On the other hand, the P2X4 receptor is also reported to be an inflammationregulated purinergic receptor. In rabbit aortic endothelium, the expression of P2X4 was upregulated after balloon injury followed by a high-fat diet [115]. A high-glucose and palmitate diet induced upregulation of $\mathrm{P} 2 \mathrm{X} 4$ and $\mathrm{P} 2 \mathrm{X} 7$ receptors accompanied by hyperpermeability of HUVEC monolayers that was attenuated by respective antagonists [116]. In line with this, ATP-mediated coronary microvascular endothelial barrier stabilisation was strengthened in the presence of P2X4 receptor antagonist (5-(3-bromophenyl)-1,3dihydro-2H-benzofuro[3,2-e]-1,4-diazepin-2-one (5-BDBD)) and attenuated in the presence of the receptor modulator ivermectin [78]. Differential effects of P2X4 receptor activation on endothelial barrier function under different experimental conditions may be partly explained by the downstream signalling mechanisms. For example, under basal conditions, ECs express high levels of endothelial NO synthase (eNOS), which has been reported to be downregulated under chronic inflammatory conditions that may result in an upregulation of reactive oxygen species production, leading to barrier failure.

Unlike P2X4 receptors, activation of P2X7 receptors in ECs is primarily linked to a proinflammatory and hyperpermeability response. In an in vitro model of the blood-brain barrier, ATP induced an increased production of matrix metallopeptidase 9 (MMP9) in an interleukin (IL)-1 $\beta$-dependent manner, which was responsible for the degradation of tight junction proteins [117]. These ATP effects were abrogated by P2X7 receptor antagonist, suggesting that they were P2X7 receptor-dependent. Similarly, hyperglycaemia induced the production of IL-1 $\beta$ via P2X7 receptor activation and caused damage to the retinal endothelial cell-cell junctions and barrier that was abrogated by a selective P2X7 receptor antagonist [118]. Likewise, in an in vivo model of intracranial haemorrhage, an upregulation of P2X7 receptor expression accompanied by the development of cranial oedema was observed. Pharmacological inhibition or siRNA-mediated knockdown of P2X7 receptors attenuated the disruption of the blood-brain barrier and the resultant oedema [88]. These effects were mediated via P2X7-induced activation of the RhoA/Rock pathway. Likewise, $\mathrm{P} 2 \mathrm{X} 7^{(-/-)}$mice were protected against traumatic brain injury-induced development of brain oedema [89] and also the development of lung inflammation and oedema in vivo [119]. In contrast, Kaiser et al. [90] reported a protective role of P2X7 
receptors in a cerebral transient IR model of brain injury and oedema formation. The mice deficient in P2X7 receptors developed more severe oedema after transient cerebral artery occlusion compared with their wild-type littermates [90].

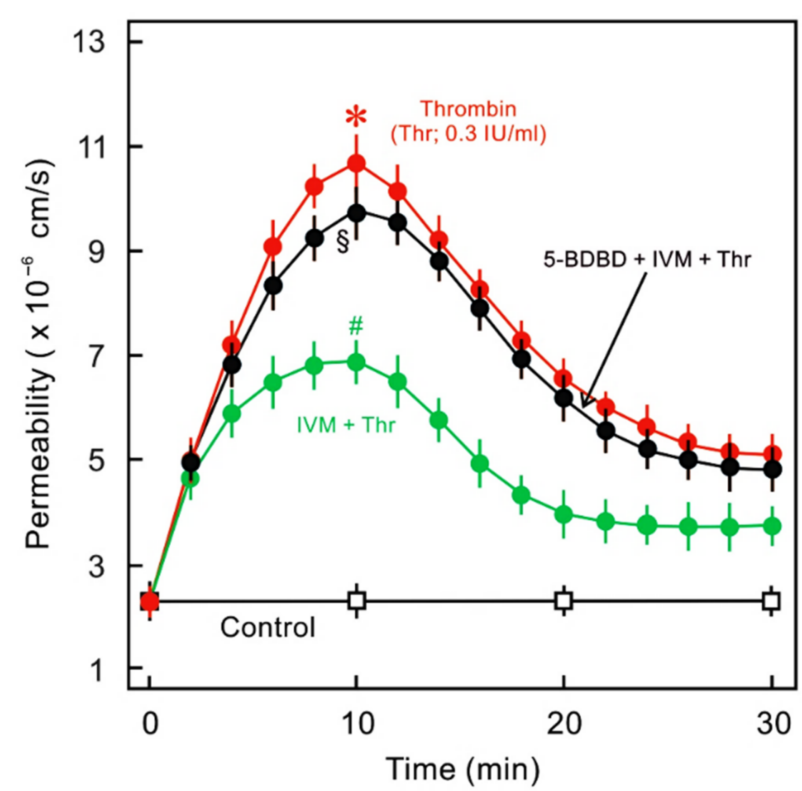

Figure 3. Effect of P2X4 receptor modulator (ivermectin; IVM) and antagonist ((5-(3-bromophenyl)1,3-dihydro-2H-benzofuro[3,2-e]-1,4-diazepin-2-one: 5-BDBD) on thrombin-induced endothelial hyperpermeability. HUVEC monolayers cultured on filter membranes were exposed to human thrombin (Thr, $0.3 \mathrm{IU} / \mathrm{mL}$ ) in the absence (red) or presence (green) of ivermectin (IVM; $50 \mu \mathrm{M}$ ) and the flux of labelled albumin was measured as described previously [84]. In a parallel set of experiments, P2X4 receptor antagonist (5-BDBD; $10 \mu \mathrm{M})$ was added before the addition of ivermectin and thrombin. $n=4,{ }^{*} p<0.05$ vs. control, $\# p<0.05$ vs. Thr alone, ${ }^{\S} p<0.05$ vs. IVM + Thr. For experimental details, please see methods in Supplementary File.

\section{P2Y Receptors and Signalling}

P2Y receptors are membrane-bound class A GPCRs for extracellular nucleotides [120]. At present, eight mammalian P2Y receptor subtypes (P2 $Y_{1}, \mathrm{P}_{2} \mathrm{Y}_{2}, \mathrm{P}_{2} \mathrm{Y}_{4}, \mathrm{P} 2 \mathrm{Y}_{6}, \mathrm{P}_{2} \mathrm{Y}_{11}$, $\mathrm{P} \mathrm{Y}_{12}, \mathrm{P}_{2} \mathrm{Y}_{13}$, and $\mathrm{P} 2 \mathrm{Y}_{14}$ ) have been cloned and are further classified into two sub-families based on sequence similarities and signal transduction pathways [121-128]. The $\mathrm{P}_{2} \mathrm{Y}_{1}$-like subfamily includes the $\mathrm{P}_{2} \mathrm{Y}_{1}, \mathrm{P}_{2} \mathrm{Y}_{2}, \mathrm{P}_{2} \mathrm{Y}_{4}, \mathrm{P}_{2} \mathrm{Y}_{6}$, and $\mathrm{P} 2 \mathrm{Y}_{11}$ receptors that are coupled to $\mathrm{G}_{\mathrm{q}}$ proteins. The $\mathrm{P} 2 \mathrm{Y}_{11}$ receptors are coupled additionally to $\mathrm{G}_{\mathrm{s}}$ proteins, activation of which leads to an activation of AC and enhanced production of cAMP $[128,129]$. The P2 $\mathrm{Y}_{12}$-like subfamily includes $\mathrm{P}_{2} \mathrm{Y}_{12}, \mathrm{P}_{2} \mathrm{Y}_{13}$, and $\mathrm{P}_{2} \mathrm{Y}_{14}$ receptors, which mediate cellular signalling via $G_{i}$ proteins [128], activation of which leads to inhibition of $A C$ and reduction in cellular cAMP levels [127,128]. Moreover, activation of several P2Y receptors is associated with activation of the MAPK pathway, and consequently these receptors are involved in cell survival and proliferation [123,130].

\section{P2Y Receptors and Endothelial Barrier}

ECs express several of the $\mathrm{P} 2 \mathrm{Y}$ receptor subtypes that are distributed over the entire vasculature. The endothelial P2Y receptors have been investigated primarily within the context of their NO-mediated vasorelaxant properties; therefore, fewer data are available in relation to their role in maintaining the endothelial barrier. The $\mathrm{P}_{2} \mathrm{Y}_{1}$ receptor is a ubiquitously expressed endothelial purinergic receptor on most $\mathrm{EC}$ types. It is a $\mathrm{G}_{\mathrm{q}^{-}}$ linked GPCR that has been well-studied in platelet biology, for which ADP acts as a natural agonist and ATP an antagonist [131,132]. P2Y 1 knockout mice are viable, fertile, normal in size, and do not present gross physical or behavioural abnormalities [133]. 
$\mathrm{P} \mathrm{Y}_{1}^{(-/-)}$homozygous mice are more susceptible to lung infections and are resistant to $\mathrm{ADP} /$ collagen-induced thrombin formation $[133,134]$. Moreover, $\mathrm{P}_{1} \mathrm{Y}^{(-/-)}$apoE $^{(-/-)}$ double knockout mice have reduced amounts of atherosclerotic lesions [91] that were not affected by transplanting wild-type bone marrow to the knockouts, suggesting the vascular but not the haematopoietic $\mathrm{P}_{2} \mathrm{Y}_{1}$ receptor may be involved in the atherogenic response [91]. Moreover, leukocyte recruitment to inflamed vessels was reduced in vivo and leukocyte transendothelial migration was reduced in $\mathrm{P}_{2} \mathrm{Y}_{1}$ knockout as well as $\mathrm{P}_{2} \mathrm{Y}_{1}$ receptor antagonist-treated ECs in vitro [135]. These studies suggest that the $\mathrm{P}_{2} \mathrm{Y}_{1}$ receptor may potentiate vascular inflammation and hyperpermeability. However, in a mouse model of traumatic brain injury, development of cerebral oedema was ameliorated in mice treated with the P2 $\mathrm{Y}_{1}$ agonist 2-methylthioadenosine $5^{\prime}$ diphosphate (2MeSADP). These protective effects of the P2Y $\mathrm{Y}_{1}$ agonist were lost in inositol 3-phosphate receptor 2 (IP3R2)-knockout mice, suggesting that it is an IP3 $/ \mathrm{Ca}^{2+}$-dependent phenomenon [92]. We observed that $\mathrm{P} \mathrm{Y}_{1}$ mRNA is expressed in HUVECs, and treatment of cultured HUVEC monolayers with ADP as well as P2Y $_{1}$-selective agonist $2 \mathrm{MeSADP}$ antagonised thrombin-induced HUVEC hyperpermeability (Figure 4). This barrier-protective effect of $\mathrm{P}_{2} \mathrm{Y}_{1}$ agonist is probably mediated via $\mathrm{G}_{\mathrm{q}} / \mathrm{IP} 3 / \mathrm{Ca}^{2+}$-dependent activation of Rac1 [136].

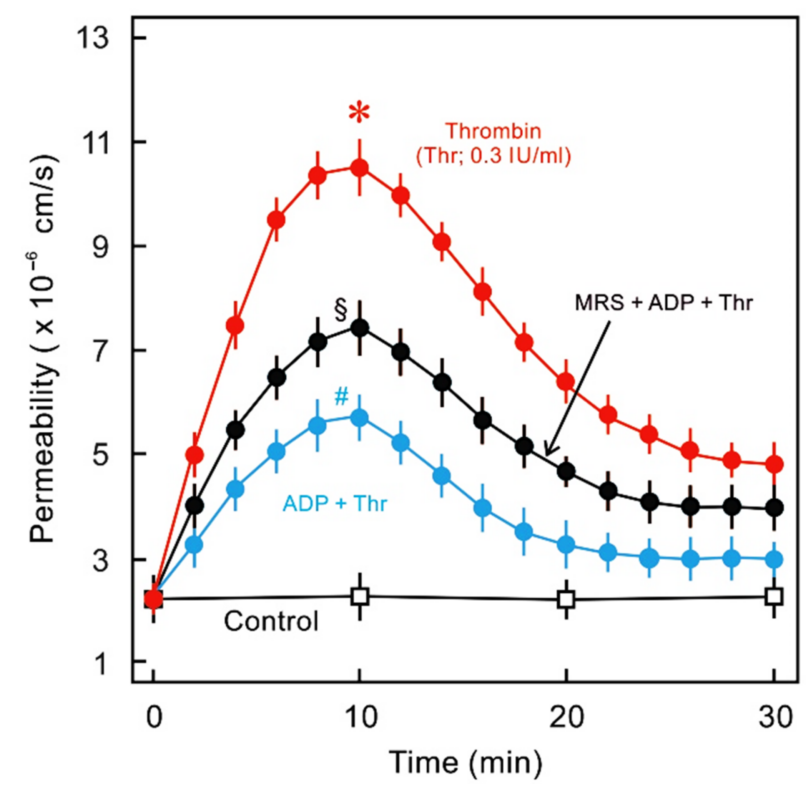

Figure 4. Effect of ADP and P2Y $\mathrm{Y}_{1}$ antagonist (MRS2500) on thrombin-induced endothelial hyperpermeability: HUVEC monolayers cultured on filter membranes were exposed to human thrombin (Thr, $0.3 \mathrm{IU} / \mathrm{mL}$ ) in the absence (red) or presence (blue) of $\mathrm{P}^{2} \mathrm{Y}_{1}$ receptor agonist ADP $(10 \mu \mathrm{M})$, and the flux of labelled albumin was measured as described previously [84]. In a parallel set of experiments $\mathrm{P}_{2} \mathrm{Y}_{1}$ receptor antagonist (MRS2500; $10 \mu \mathrm{M}$; black) was added before the addition of ADP and thrombin. $n=4{ }^{*} p<0.05$ vs. control, \# $p<0.05$ vs. Thr alone, ${ }^{\S} p<0.05$ vs. ADP + Thr.

P2Y $\mathrm{Y}_{2}$ and $\mathrm{P}_{2} \mathrm{Y}_{4}$ are $\mathrm{G}_{\mathrm{q}} / \mathrm{G}_{11}$-coupled receptors that are activated by both UTP and ATP [128]. Global deletion of the $\mathrm{P}_{2} \mathrm{Y}_{2}$ gene reduces shear stress-induced vasodilation

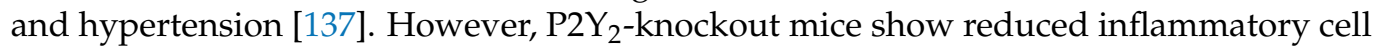
infiltration into injured vessels [138], and endothelial-specific deletion of the $\mathrm{P}_{2} \mathrm{Y}_{2}$ receptor in apo $\mathrm{E}^{(-/-)}$mice results in reduced inflammatory response and increased plaque stability [93], suggesting a pathological role of chronic $\mathrm{P}_{2} \mathrm{Y}_{2}$ receptor activation under inflammatory conditions. Accordingly, knockdown of P2Y $\mathrm{Y}_{2}$ receptors in HUVECs ameliorated LPS-induced transendothelial migration of activated neutrophils [139].

$\mathrm{P} \mathrm{Y}_{4}$-null mice are viable but display microcardia (small hearts), suggesting that the $\mathrm{P} \mathrm{Y}_{4}$ receptor plays a role in postnatal heart development [140]. Interestingly, cardiac ECs and not cardiomyocytes express the $\mathrm{P}_{2} \mathrm{Y}_{4}$ receptor, and loss of the $\mathrm{P}_{2} \mathrm{Y}_{4}$ receptor in cardiac 
ECs results in reduced growth and migratory capacity in vitro [140]. Surprisingly, $\mathrm{P} \mathrm{Y}_{4}$ knockout mice are protected from myocardial ischaemic injury, cardiac inflammation, and fibrosis in a left anterior descending (LAD) coronary artery ligation model [94]. Moreover, $\mathrm{P}_{2} \mathrm{Y}_{4}$-knockout mice are protected from an LPS-induced cardiac microvascular hyperpermeability response. These data suggest that although the endothelial $\mathrm{P}_{2} \mathrm{Y}_{4}$ receptor is required for normal development of the heart in mice, its activation may induce vascular hyperpermeability under pathological conditions.

$\mathrm{P} \mathrm{Y}_{6}$ is a $\mathrm{G}_{\mathrm{q}}$-coupled receptor activated by UDP [128] that is expressed on aortic and cerebral ECs $[141,142]$. Global loss of $\mathrm{P}_{2} \mathrm{Y}_{6}$ receptors results in macrocardia (larger heart), and mice lacking the $\mathrm{P}_{2} \mathrm{Y}_{6}$ receptor show an amplified pathological cardiac hypertrophic response [143]. However, vascular deficiency of $\mathrm{P}_{2} \mathrm{Y}_{6}$ receptors results in reduced vascular inflammation and ameliorated neointima formation in an atherosclerosis mouse model $[95,144]$. In contrast, inhibition of cerebral ${\mathrm{P} 2 \mathrm{Y}_{6}}_{6}$ receptors with a selective antagonist aggravates development of cerebral oedema in a mouse model of ischaemic brain injury [145].

$\mathrm{P}^{2} \mathrm{Y}_{11}$ is the only known human P2Y receptor coupled to $\mathrm{G}_{\mathrm{S}}[124,128,129]$. The murine orthologue of the $\mathrm{P}_{2} \mathrm{Y}_{11}$ receptor does not exist or at least has not yet been identified. Moreover, the lack of selective agonists and antagonists for this receptor as well as specific detection tools (antibodies) make functional investigations of the $\mathrm{P}_{2} \mathrm{Y}_{11}$ receptor difficult [146]. We did not detect P2Y $\mathrm{Y}_{11}$ mRNA in HUVECs, but other EC types were not investigated. Presumably, if it is expressed in some EC type, one would expect its activation would raise intracellular cAMP levels that can interact with multiple signalling pathways, e.g., Rac1-dependent actin cytoskeleton rearrangement and MLCP-mediated inactivation of the contractile machinery, thus modulating endothelial barrier properties.

The P2 $\mathrm{Y}_{12}$-like subfamily comprises three members: $\mathrm{P}_{2} \mathrm{Y}_{12}, \mathrm{P}_{2} \mathrm{Y}_{13}$, and $\mathrm{P} 2 \mathrm{Y}_{14}$. All of these receptors are coupled to $G_{i}$, and their activation leads to suppression of AC activity and cAMP production [128]. $\mathrm{P}_{2} \mathrm{Y}_{12}$ is well-studied in relation to platelet biology, and its antagonists are used clinically as anticoagulants in various pathological conditions. In human cardiac-derived mesenchymal cells, ticagrelor, a $\mathrm{P}_{2} \mathrm{Y}_{12}$ receptor antagonist, induces the release of anti-apoptotic exosomes [147] that may also modulate the coronary microvascular endothelial barrier. Endothelial expression of both P2 $\mathrm{Y}_{12}[84,148]$ and P2 $\mathrm{Y}_{13}[104]$ has been documented. Recently, we demonstrated the expression of $\mathrm{P}_{2} \mathrm{Y}_{12}$ receptor mRNA and protein in HUVECs, and a specific $\mathrm{P}_{2} \mathrm{Y}_{12}$ antagonist increased intracellular cAMP levels and protected against thrombin-induced hyperpermeability [84]. We also observed the expression of $\mathrm{P}_{2} \mathrm{Y}_{13}$ but not $\mathrm{P}_{2} \mathrm{Y}_{14}$ mRNA in primary HUVECs (unpublished). In vasa vasorum ECs, ADP mediates a mitogenic response partly via $\mathrm{P}_{2} \mathrm{Y}_{13}$ receptors [104]. The expression of $\mathrm{P}_{2} \mathrm{Y}_{14}$ receptor has been reported in rat primary brain microvascular ECs [149], and activation of this receptor induces a pro-inflammatory response in ECs. Moreover, UDP-glucose (an agonist for $\mathrm{P}_{2} \mathrm{Y}_{14}$ receptor) mediated a contractile response in isolated pancreatic arteries in an endothelium-dependent manner, and this effect was abrogated by a selective $\mathrm{P}_{2} \mathrm{Y}_{14}$ receptor antagonist [150]. No further data are available related to the involvement of $\mathrm{P}_{2} \mathrm{Y}_{13}$ and $\mathrm{P}_{2} \mathrm{Y}_{14}$ receptors in the control of endothelial barrier properties. Figure 5 presents an overview about the effects of various P2Y receptors' activation on endothelial barrier function. 


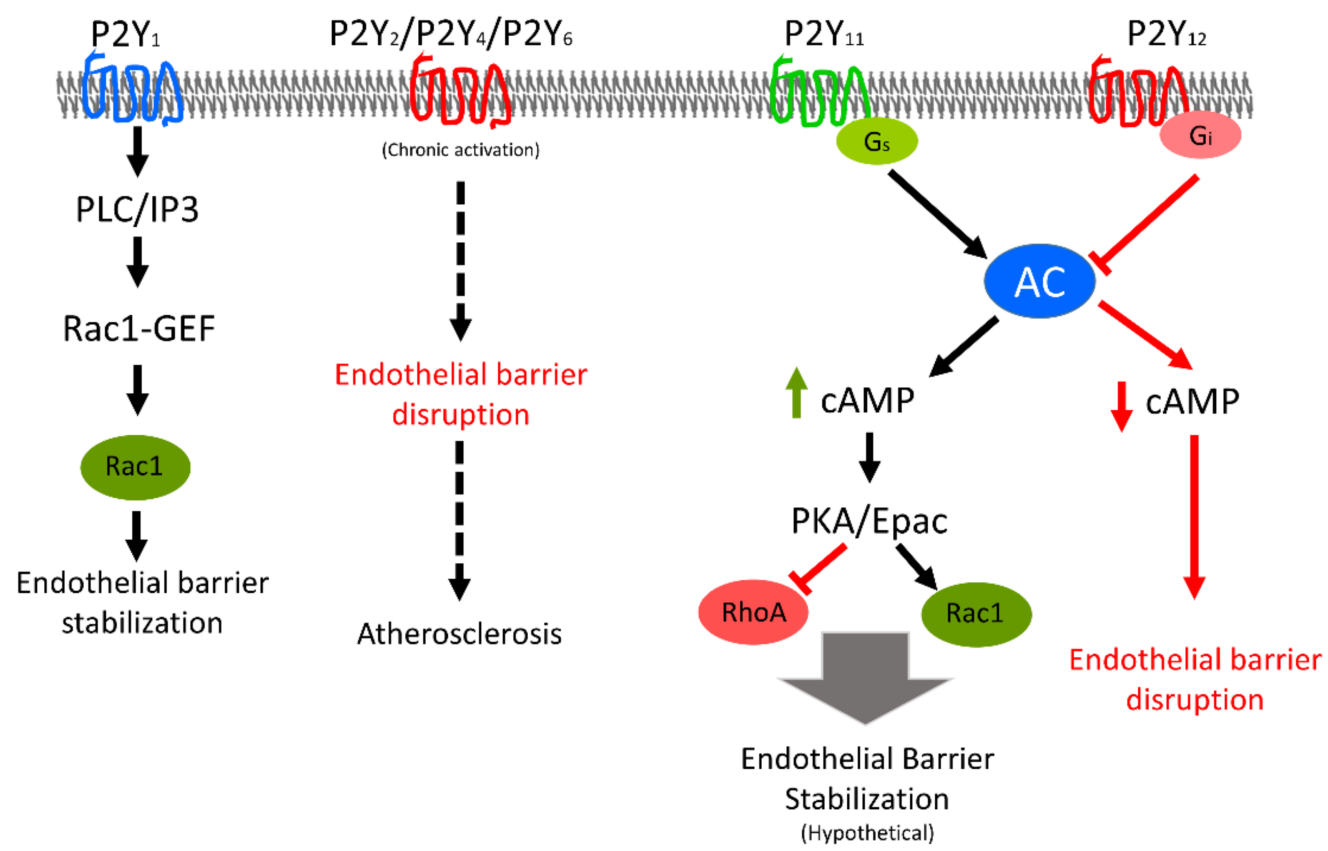

Figure 5. Schematic presentation of effect of various P2Y receptors' activation on endothelial barrier function. Activation of $\mathrm{P}_{2} \mathrm{Y}_{1}$ receptor stabilises while chronic activation of $\mathrm{P}_{2} \mathrm{Y}_{2}, \mathrm{P}_{2} \mathrm{Y}_{4}$, and $\mathrm{P} 2 \mathrm{Y}_{6}$ receptors results in atherosclerosis. Loss of endothelial barrier integrity is one of the early features of development of atherosclerotic plaques. The molecular mechanisms are not clear yet. $\mathrm{P}_{2} \mathrm{Y}_{12}$ receptor is $\mathrm{G}_{\mathrm{i}}$-linked and its activation results in inhibition of adenylyl cyclase (AC) and reduction in intracellular cAMP content that leads to endothelial barrier destabilisation. The P2Y 11 is $\mathrm{G}_{\mathrm{s}}$-linked and its activation would lead to opposite effects and endothelial barrier stabilisation. The effects of $\mathrm{P}_{2} \mathrm{Y}_{11}$ are hypothetical based on available information about the $\mathrm{P}_{2} \mathrm{Y}_{11}$ receptor. Black solid arrows indicate sequence of signalling, broken arrows indicate multiple steps in between, green arrow shows increase in cellular cAMP levels, and red arrows indicate signalling via Gi leading to reduction in cAMP and endothelial barrier disruption. Red blocks mean inhibition.

\section{Conclusions and Perspective}

Endothelial barrier properties are influenced by extracellular nucleotides via activation of various purinergic receptors. The response depends on the type of receptor(s) present and the local concentration of the nucleotides. Adenosine, primarily via activation of $\mathrm{A}_{2 \mathrm{~A}}$ and $A_{2 B}$ receptors, raises intracellular levels of cAMP in the lung microvascular bed and thus strengthens the barrier properties and ameliorates hypoxia- and inflammation-induced development of oedema. Selective agonists for adenosine $A_{2}$ receptors are available that may be tested (for local application) for clinical use in various oedematous abnormalities of the lung, e.g., acute lung injury. Conversely, $\mathrm{A}_{2}$ receptor activation in brain and coronary microvasculature results in transient opening of the cell-cell junction in a cAMP-dependent manner. This property of the brain microvasculature can be exploited for local delivery of drugs to the CNS. P2 receptors are also widely distributed in the vascular bed. Chronic P2X receptor activation leads to endothelial barrier destabilisation and oedema formation, an effect primarily attributed to the P2X7 receptors. There is a need for the development of more selective and potent $\mathrm{P} 2 \mathrm{X} 7$ receptor antagonists to ameliorate inflammation-induced loss of endothelial barrier function. There is also a lack of selective P2Y receptor agonists and antagonists, which makes the investigation of P2Y receptors in relation to endothelial barrier function difficult. We and others have documented that ATP at low micromolar concentrations stabilises endothelial barrier function, mainly via activation of various P2Y receptors, whereas at high concentration (in the millimolar range), it may act as a danger-associated molecular pattern (DAMP) [151], amplifying the inflammatory response. Inhibition of the $\mathrm{P}_{2} \mathrm{Y}_{12}$ receptor blocks inflammation-induced increases in endothelial 
permeability [84]. Further studies are needed to identify specific P2Y receptors that mediate endothelial barrier stabilisation and destabilisation.

Supplementary Materials: The following are available online at https:/ / www.mdpi.com/1422-006 7/22/3/1207/s1.

Author Contributions: M.A., D.G., and R.S. conceptualised the manuscript. M.A. and D.G. wrote the manuscript. M.A. prepared the figures. C.T., J.H., C.W.H. and R.S. critically reviewed and appraised the manuscript. All authors have read and agreed to the published version of the manuscript.

Funding: The study was supported by University of Giessen Anschubfinanzierung grant to M. Aslam and UKGM grant (No. 62589122) to D. Gündüz.

Institutional Review Board Statement: The study was conducted according to the guidelines of the Declaration of Helsinki, and approved by the Ethics Committee of Medical Faculty of Justus-Liebig University (Approval no. AZ132/09 dated 29 October 2009).

Informed Consent Statement: Informed consent was obtained from all subjects involved in the study.

Data Availability Statement: The data presented in this study are available within the manuscript.

Acknowledgments: The technical support by S. Schäffer, D. Reitz, and H. Thomas is gratefully acknowledged. In preparing the figures, some illustrations were used from open access "Library of Science and Medical Illustration" https:/ / gumroad.com/l/library.

Conflicts of Interest: The authors declare no conflict of interest.

$\begin{array}{ll}\text { Abbreviations } \\ \text { AJ } & \text { Adherens junctions } \\ \text { ADP } & \text { Adenosine } 5^{\prime} \text {-diphosphate } \\ \text { AMP } & \text { Adenosine } 5^{\prime} \text {-monophosphate } \\ \text { ATP } & \text { Adenosine } 5^{\prime} \text {-triphosphate } \\ \text { cAMP } & \text { 3' }^{\prime} 5^{\prime} \text {-cyclic adenosine monophosphate } \\ \text { DAMP } & \text { Danger-associated molecular pattern } \\ \text { DPCPX } & \text { 8-Cyclopentyl-1,3-dipropylxanthine } \\ \text { ER } & \text { Endoplasmic reticulum } \\ \text { ERK } & \text { Extracellular signal-regulated kinase } \\ \text { GPCR } & \text { G protein-coupled receptor } \\ \text { H/R } & \text { Hypoxia-reoxygenation } \\ \text { HUVEC } & \text { Human umbilical vein endothelial cells } \\ \text { I/R } & \text { Ischaemia reperfusion } \\ \text { LPS } & \text { Lipopolysaccharide } \\ \text { MAPK } & \text { Mitogen-activated protein kinase } \\ \text { MEK } & \text { MAPK/ERK kinase } 1 \\ \text { MLCK } & \text { Myosin light-chain kinase } \\ \text { MLCP } & \text { Myosin light-chain phosphatase } \\ \text { MMP9 } & \text { matrix metallopeptidase 9 } \\ \text { MYPT1 } & \text { Myosin phosphatase targeting subunit 1 } \\ \text { NECA } & \text { 5'-N-Ethylcarboxamidoadenosine } \\ \text { PKC } & \text { Protein kinase C } \\ \text { ROCK } & \text { Rho-associated kinase } \\ \text { ROS } & \text { Reactive oxygen species } \\ \text { UDP } & \text { Uridine diphosphate } \\ \text { UTP } & \text { Uridine triphosphate } \\ \text { XAC } & \text { Xanthine amine congener } \\ \text { VE } & \text { Vascular endothelium } \\ \text { vWF } & \text { von Willebrand Factor } \\ \text { ZO-1 } & \text { Zonula occludens-1 } \\ & \end{array}$




\section{References}

1. Komarova, Y.A.; Kruse, K.; Mehta, D.; Malik, A.B. Protein Interactions at Endothelial Junctions and Signaling Mechanisms Regulating Endothelial Permeability. Circ. Res. 2017, 120, 179-206. [CrossRef]

2. Wettschureck, N.; Strilic, B.; Offermanns, S. Passing the Vascular Barrier: Endothelial Signaling Processes Controlling Extravasation. Physiol. Rev. 2019, 99, 1467-1525. [CrossRef]

3. Kumar, P.; Shen, Q.; Pivetti, C.D.; Lee, E.S.; Wu, M.H.; Yuan, S.Y. Molecular mechanisms of endothelial hyperpermeability: Implications in inflammation. Expert. Rev. Mol. Med. 2009, 11, e19. [CrossRef] [PubMed]

4. Daniel, A.E.; van Buul, J.D. Endothelial junction regulation: A prerequisite for leukocytes crossing the vessel wall. J. Innate Immun. 2013, 5, 324-335. [CrossRef]

5. Mehta, D.; Malik, A.B. Signaling mechanisms regulating endothelial permeability. Physiol. Rev. 2006, 86, 279-367. [CrossRef] [PubMed]

6. Lampugnani, M.G.; Corada, M.; Caveda, L.; Breviario, F.; Ayalon, O.; Geiger, B.; Dejana, E. The molecular organization of endothelial cell to cell junctions: Differential association of plakoglobin, beta-catenin, and alpha-catenin with vascular endothelial cadherin (VE-cadherin). J. Cell Biol. 1995, 129, 203-217. [CrossRef] [PubMed]

7. Dejana, E.; Orsenigo, F.; Lampugnani, M.G. The role of adherens junctions and VE-cadherin in the control of vascular permeability. J. Cell Sci. 2008, 121, 2115-2122. [CrossRef] [PubMed]

8. Wojciak-Stothard, B.; Tsang, L.Y.; Haworth, S.G. Rac and Rho play opposing roles in the regulation of hypoxia/reoxygenationinduced permeability changes in pulmonary artery endothelial cells. Am. J. Physiol. Lung Cell. Mol. Physiol. 2005, 288, L749-L760. [CrossRef] [PubMed]

9. Wojciak-Stothard, B.; Tsang, L.Y.; Paleolog, E.; Hall, S.M.; Haworth, S.G. Rac1 and RhoA as regulators of endothelial phenotype and barrier function in hypoxia-induced neonatal pulmonary hypertension. Am. J. Physiol. Lung Cell. Mol. Physiol. 2006, 290, L1173-L1182. [CrossRef]

10. Wysolmerski, R.B.; Lagunoff, D. Regulation of permeabilized endothelial cell retraction by myosin phosphorylation. Am. $J$ Physiol. 1991, 261, C32-C40. [CrossRef]

11. Goeckeler, Z.M.; Wysolmerski, R.B. Myosin phosphatase and cofilin mediate cAMP/cAMP-dependent protein kinase-induced decline in endothelial cell isometric tension and myosin II regulatory light chain phosphorylation. J. Biol. Chem. 2005, 280, 33083-33095. [CrossRef]

12. Birukova, A.A.; Smurova, K.; Birukov, K.G.; Kaibuchi, K.; Garcia, J.G.; Verin, A.D. Role of Rho GTPases in thrombin-induced lung vascular endothelial cells barrier dysfunction. Microvasc. Res. 2004, 67, 64-77. [CrossRef] [PubMed]

13. Nguyen, D.H.; Catling, A.D.; Webb, D.J.; Sankovic, M.; Walker, L.A.; Somlyo, A.V.; Weber, M.J.; Gonias, S.L. Myosin light chain kinase functions downstream of Ras/ERK to promote migration of urokinase-type plasminogen activator-stimulated cells in an integrin-selective manner. J. Cell Biol. 1999, 146, 149-164. [CrossRef]

14. Gündüz, D.; Troidl, C.; Tanislav, C.; Rohrbach, S.; Hamm, C.; Aslam, M. Role of PI3K/Akt and MEK/ERK Signalling in cAMP/Epac-Mediated Endothelial Barrier Stabilisation. Front. Physiol. 2019, 10, 1387.

15. Goeckeler, Z.M.; Wysolmerski, R.B. Myosin light chain kinase-regulated endothelial cell contraction: The relationship between isometric tension, actin polymerization, and myosin phosphorylation. J. Cell Biol. 1995, 130, 613-627. [CrossRef] [PubMed]

16. Bergfeld, G.R.; Forrester, T. Release of ATP from human erythrocytes in response to a brief period of hypoxia and hypercapnia. Cardiovasc. Res. 1992, 26, 40-47. [CrossRef]

17. Communi, D.; Janssens, R.; Suarez-Huerta, N.; Robaye, B.; Boeynaems, J.M. Advances in signalling by extracellular nucleotides. The role and transduction mechanisms of P2Y receptors. Cell. Signal. 2000, 12, 351-360. [CrossRef]

18. Beigi, R.; Kobatake, E.; Aizawa, M.; Dubyak, G.R. Detection of local ATP release from activated platelets using cell surface-attached firefly luciferase. Am. J. Physiol. 1999, 276, C267-C278. [CrossRef]

19. Buxton, I.L.; Kaiser, R.A.; Oxhorn, B.C.; Cheek, D.J. Evidence supporting the Nucleotide Axis Hypothesis: ATP release and metabolism by coronary endothelium. Am. J. Physiol. Heart Circ. Physiol. 2001, 281, H1657-H1666. [CrossRef]

20. Gödecke, S.; Roderigo, C.; Rose, C.R.; Rauch, B.H.; Godecke, A.; Schrader, J. Thrombin-induced ATP release from human umbilical vein endothelial cells. Am. J. Physiol. Cell Physiol. 2012, 302, C915-C923. [CrossRef]

21. Gündüz, D.; Kasseckert, S.A.; Härtel, F.V.; Aslam, M.; Abdallah, Y.; Schäfer, M.; Piper, H.M.; Noll, T.; Schäfer, C. Accumulation of extracellular ATP protects against acute reperfusion injury in rat heart endothelial cells. Cardiovasc. Res. 2006, 71, 764-773. [CrossRef] [PubMed]

22. Bodin, P.; Milner, P.; Winter, R.; Burnstock, G. Chronic hypoxia changes the ratio of endothelin to ATP release from rat aortic endothelial cells exposed to high flow. Proc. R. Soc. B Biol. Sci. 1992, 247, 131-135. [CrossRef]

23. Gündüz, D.; Hirche, F.; Härtel, F.V.; Rodewald, C.W.; Schäfer, M.; Pfitzer, G.; Piper, H.M.; Noll, T. ATP antagonism of thrombininduced endothelial barrier permeability. Cardiovasc. Res. 2003, 59, 470-478. [CrossRef]

24. Härtel, F.V.; Rodewald, C.W.; Aslam, M.; Gündüz, D.; Hafer, L.; Neumann, J.; Piper, H.M.; Noll, T. Extracellular ATP induces assembly and activation of the myosin light chain phosphatase complex in endothelial cells. Cardiovasc. Res. 2007, 74, 487-496. [CrossRef] [PubMed]

25. Vischer, U.M.; Wollheim, C.B. Purine nucleotides induce regulated secretion of von Willebrand factor: Involvement of cytosolic $\mathrm{Ca}^{2+}$ and cyclic adenosine monophosphate-dependent signaling in endothelial exocytosis. Blood 1998, 91, 118-127. [CrossRef] [PubMed] 
26. Dushpanova, A.; Agostini, S.; Ciofini, E.; Cabiati, M.; Casieri, V.; Matteucci, M.; Del Ry, S.; Clerico, A.; Berti, S.; Lionetti, V. Gene silencing of endothelial von Willebrand Factor attenuates angiotensin II-induced endothelin-1 expression in porcine aortic endothelial cells. Sci. Rep. 2016, 6, 30048. [CrossRef] [PubMed]

27. Burnstock, G. Purinergic Signaling in the Cardiovascular System. Circ. Res. 2017, 120, 207-228. [CrossRef]

28. Burnstock, G. Purine and purinergic receptors. Brain Neurosci. Adv. 2018, 2. [CrossRef]

29. Ralevic, V.; Dunn, W.R. Purinergic transmission in blood vessels. Auton. Neurosci. 2015, 191, 48-66. [CrossRef] [PubMed]

30. Burnstock, G.; Knight, G.E. Cell culture: Complications due to mechanical release of ATP and activation of purinoceptors. Cell Tissue Res. 2017, 370, 1-11. [CrossRef]

31. Haselton, F.R.; Alexander, J.S. Platelets and a platelet-released factor enhance endothelial barrier. Am. J. Physiol. 1992, 263, L670-L678. [CrossRef] [PubMed]

32. Idzko, M.; Ferrari, D.; Riegel, A.K.; Eltzschig, H.K. Extracellular nucleotide and nucleoside signaling in vascular and blood disease. Blood 2014, 124, 1029-1037. [CrossRef] [PubMed]

33. Newby, A.C. The role of adenosine kinase in regulating adenosine concentration. Biochem. J. 1985, 226, 343-344. [CrossRef] [PubMed]

34. Newby, A.C.; Worku, Y.; Holmquist, C.A. Adenosine formation. Evidence for a direct biochemical link with energy metabolism. Adv. Myocardiol. 1985, 6, 273-284. [PubMed]

35. Eltzschig, H.K. Adenosine: An old drug newly discovered. Anesthesiology 2009, 111, 904-915. [CrossRef]

36. De Filippo, E.; Hinz, S.; Pellizzari, V.; Deganutti, G.; El-Tayeb, A.; Navarro, G.; Franco, R.; Moro, S.; Schiedel, A.C.; Müller, C.E. $A_{2 A}$ and $A_{2 B}$ adenosine receptors: The extracellular loop 2 determines high $\left(A_{2 A}\right)$ or low affinity $\left(A_{2 B}\right)$ for adenosine. Biochem. Pharmacol. 2020, 172, 113718. [CrossRef] [PubMed]

37. Borea, P.A.; Gessi, S.; Merighi, S.; Vincenzi, F.; Varani, K. Pharmacology of Adenosine Receptors: The State of the Art. Physiol. Rev. 2018, 98, 1591-1625. [CrossRef]

38. Chen, J.F.; Eltzschig, H.K.; Fredholm, B.B. Adenosine receptors as drug targets-What are the challenges? Nat. Rev. Drug Discov. 2013, 12, 265-286. [CrossRef]

39. Shim, J.O.; Shin, C.Y.; Lee, T.S.; Yang, S.J.; An, J.Y.; Song, H.J.; Kim, T.H.; Huh, I.H.; Sohn, U.D. Signal transduction mechanism via adenosine $A_{1}$ receptor in the cat esophageal smooth muscle cells. Cell Signal. 2002, 14, 365-372. [CrossRef]

40. Fenton, R.A.; Shea, L.G.; Doddi, C.; Dobson, J.G., Jr. Myocardial adenosine A A $_{1}$-receptor-mediated adenoprotection involves phospholipase C, PKC-epsilon, and p38 MAPK, but not HSP27. Am. J. Physiol. Heart Circ. Physiol. 2010, 298, H1671-H1678. [CrossRef]

41. Robin, E.; Sabourin, J.; Benoit, R.; Pedretti, S.; Raddatz, E. Adenosine $\mathrm{A}_{1}$ receptor activation is arrhythmogenic in the developing heart through NADPH oxidase/ERK- and PLC/PKC-dependent mechanisms. J. Mol. Cell Cardiol. 2011, 51, 945-954. [CrossRef] [PubMed]

42. Sterin-Borda, L.; Gomez, R.M.; Borda, E. Role of nitric oxide/cyclic GMP in myocardial adenosine $A_{1}$ receptor-inotropic response. Br. J. Pharmacol. 2002, 135, 444-450. [CrossRef] [PubMed]

43. Nayeem, M.A.; Matherne, G.P.; Mustafa, S.J. Ischemic and pharmacological preconditioning induces further delayed protection in transgenic mouse cardiac myocytes over-expressing adenosine $\mathrm{A}_{1}$ receptors (A1AR): Role of A1AR, iNOS and K(ATP) channels. Naunyn-Schmiedeberg's Arch. Pharmacol. 2003, 367, 219-226. [CrossRef] [PubMed]

44. Umemiya, M.; Berger, A.J. Activation of adenosine $A_{1}$ and $A_{2}$ receptors differentially modulates calcium channels and glycinergic synaptic transmission in rat brainstem. Neuron 1994, 13, 1439-1446. [CrossRef]

45. Schulte, G.; Fredholm, B.B. Signalling from adenosine receptors to mitogen-activated protein kinases. Cell. Signal. 2003, 15, 813-827. [CrossRef]

46. Layland, J.; Carrick, D.; Lee, M.; Oldroyd, K.; Berry, C. Adenosine: Physiology, pharmacology, and clinical applications. JACC Cardiovasc. Interv. 2014, 7, 581-591. [CrossRef]

47. Eckle, T.; Fullbier, L.; Wehrmann, M.; Khoury, J.; Mittelbronn, M.; Ibla, J.; Rosenberger, P.; Eltzschig, H.K. Identification of ectonucleotidases CD39 and CD73 in innate protection during acute lung injury. J. Immunol. 2007, 178, 8127-8137. [CrossRef]

48. Reece, T.B.; Ellman, P.I.; Maxey, T.S.; Crosby, I.K.; Warren, P.S.; Chong, T.W.; LeGallo, R.D.; Linden, J.; Kern, J.A.; Tribble, C.G.; et al. Adenosine $A_{2 A}$ receptor activation reduces inflammation and preserves pulmonary function in an in vivo model of lung transplantation. J. Thorac. Cardiovasc. Surg. 2005, 129, 1137-1143. [CrossRef]

49. Eckle, T.; Grenz, A.; Laucher, S.; Eltzschig, H.K. A $\mathrm{A}_{2 \mathrm{~B}}$ adenosine receptor signaling attenuates acute lung injury by enhancing alveolar fluid clearance in mice. J. Clin. Investig. 2008, 118, 3301-3315. [CrossRef]

50. Khimenko, P.L.; Moore, T.M.; Hill, L.W.; Wilson, P.S.; Coleman, S.; Rizzo, A.; Taylor, A.E. Adenosine $\mathrm{A}_{2}$ receptors reverse ischemia-reperfusion lung injury independent of beta-receptors. J. Appl. Physiol. 1995, 78, 990-996. [CrossRef]

51. Konrad, F.M.; Neudeck, G.; Vollmer, I.; Ngamsri, K.C.; Thiel, M.; Reutershan, J. Protective effects of pentoxifylline in pulmonary inflammation are adenosine receptor $\mathrm{A}_{2 \mathrm{~A}}$ dependent. FASEB J. 2013, 27, 3524-3535. [CrossRef] [PubMed]

52. Konrad, F.M.; Witte, E.; Vollmer, I.; Stark, S.; Reutershan, J. Adenosine receptor $\mathrm{A}_{2} \mathrm{~b}$ on hematopoietic cells mediates LPS-induced migration of PMNs into the lung interstitium. Am. J. Physiol. Lung Cell Mol. Physiol. 2012, 303, L425-L438. [CrossRef] [PubMed]

53. Lu, Q.; Harrington, E.O.; Newton, J.; Casserly, B.; Radin, G.; Warburton, R.; Zhou, Y.; Blackburn, M.R.; Rounds, S. Adenosine protected against pulmonary edema through transporter- and receptor $\mathrm{A}_{2}$-mediated endothelial barrier enhancement. Am. J. Physiol. Lung Cell. Mol. Physiol. 2010, 298, L755-L767. [PubMed] 
54. Pfeil, U.; Aslam, M.; Paddenberg, R.; Quanz, K.; Chang, C.L.; Park, J.I.; Gries, B.; Rafiq, A.; Faulhammer, P.; Goldenberg, A.; et al. Intermedin/adrenomedullin-2 is a hypoxia-induced endothelial peptide that stabilizes pulmonary microvascular permeability. Am. J. Physiol. Lung Cell Mol. Physiol. 2009, 297, L837-L845. [CrossRef]

55. Blackburn, M.R.; Volmer, J.B.; Thrasher, J.L.; Zhong, H.; Crosby, J.R.; Lee, J.J.; Kellems, R.E. Metabolic consequences of adenosine deaminase deficiency in mice are associated with defects in alveogenesis, pulmonary inflammation, and airway obstruction. $J$. Exp. Med. 2000, 192, 159-170.

56. Zhou, Y.; Mohsenin, A.; Morschl, E.; Young, H.W.; Molina, J.G.; Ma, W.; Sun, C.X.; Martinez-Valdez, H.; Blackburn, M.R. Enhanced airway inflammation and remodeling in adenosine deaminase-deficient mice lacking the $\mathrm{A}_{2 \mathrm{~B}}$ adenosine receptor. J. Immunol. 2009, 182, 8037-8046. [CrossRef]

57. Neely, C.F.; Keith, I.M. A 1 adenosine receptor antagonists block ischemia-reperfusion injury of the lung. Am. J. Physiol. 1995, 268, L1036-L1046. [CrossRef]

58. Neely, C.F.; Jin, J.; Keith, I.M. A 1 -adenosine receptor antagonists block endotoxin-induced lung injury. Am. J. Physiol. 1997, 272, L353-L361. [CrossRef]

59. Mulloy, D.P.; Sharma, A.K.; Fernandez, L.G.; Zhao, Y.; Lau, C.L.; Kron, I.L.; Laubach, V.E. Adenosine A 3 receptor activation attenuates lung ischemia-reperfusion injury. Ann. Thorac. Surg. 2013, 95, 1762-1767.

60. Kadry, H.; Noorani, B.; Cucullo, L. A blood-brain barrier overview on structure, function, impairment, and biomarkers of integrity. Fluids Barriers CNS 2020, 17, 69.

61. Kalaria, R.N.; Harik, S.I. Adenosine receptors and the nucleoside transporter in human brain vasculature. J. Cereb. Blood Flow Metab. 1988, 8, 32-39. [CrossRef] [PubMed]

62. Mills, J.H.; Alabanza, L.; Weksler, B.B.; Couraud, P.O.; Romero, I.A.; Bynoe, M.S. Human brain endothelial cells are responsive to adenosine receptor activation. Purinergic Signal. 2011, 7, 265-273. [CrossRef] [PubMed]

63. Carman, A.J.; Mills, J.H.; Krenz, A.; Kim, D.G.; Bynoe, M.S. Adenosine receptor signaling modulates permeability of the blood-brain barrier. J. Neurosci. 2011, 31, 13272-13280. [CrossRef] [PubMed]

64. Mills, J.H.; Thompson, L.F.; Mueller, C.; Waickman, A.T.; Jalkanen, S.; Niemela, J.; Airas, L.; Bynoe, M.S. CD73 is required for efficient entry of lymphocytes into the central nervous system during experimental autoimmune encephalomyelitis. Proc. Natl. Acad. Sci. USA 2008, 105, 9325-9330. [CrossRef] [PubMed]

65. Zhou, Y.; Zeng, X.; Li, G.; Yang, Q.; Xu, J.; Zhang, M.; Mao, X.; Cao, Y.; Wang, L.; Xu, Y.; et al. Inactivation of endothelial adenosine $\mathrm{A}_{2 \mathrm{~A}}$ receptors protects mice from cerebral ischaemia-induced brain injury. Br. J. Pharmacol. 2019, 176, $2250-2263$.

66. Kim, D.G.; Bynoe, M.S. A 2 Adenosine Receptor Regulates the Human Blood-Brain Barrier Permeability. Mol. Neurobiol. 2015, 52, 664-678. [CrossRef]

67. Caporarello, N.; Olivieri, M.; Cristaldi, M.; Scalia, M.; Toscano, M.A.; Genovese, C.; Addamo, A.; Salmeri, M.; Lupo, G.; Anfuso, C.D. Blood-Brain Barrier in a Haemophilus influenzae Type a In Vitro Infection: Role of Adenosine Receptors $\mathrm{A}_{2 \mathrm{~A}}$ and $\mathrm{A}_{2 \mathrm{~B}}$. Mol. Neurobiol. 2018, 55, 5321-5336. [CrossRef] [PubMed]

68. Zhao, Z.; Shang, X.; Chen, Y.; Zheng, Y.; Huang, W.; Jiang, H.; Lv, Q.; Kong, D.; Jiang, Y.; Liu, P. Bacteria elevate extracellular adenosine to exploit host signaling for blood-brain barrier disruption. Virulence 2020, 11, 980-994. [CrossRef]

69. Jackson, S.; Anders, N.M.; Mangraviti, A.; Wanjiku, T.M.; Sankey, E.W.; Liu, A.; Brem, H.; Tyler, B.; Rudek, M.A.; Grossman, S.A. The effect of regadenoson-induced transient disruption of the blood-brain barrier on temozolomide delivery to normal rat brain. J. Neurooncol. 2016, 126, 433-439. [CrossRef]

70. Gao, X.; Qian, J.; Zheng, S.; Changyi, Y.; Zhang, J.; Ju, S.; Zhu, J.; Li, C. Overcoming the blood-brain barrier for delivering drugs into the brain by using adenosine receptor nanoagonist. ACS Nano 2014, 8, 3678-3689. [CrossRef]

71. Sun, Z.; Zhong, X.L.; Zong, Y.; Wu, Z.C.; Zhang, Q.; Yu, J.T.; Tan, L. Activation of adenosine receptor potentiates the anticonvulsant effect of phenytoin against amygdala kindled seizures. CNS Neurol. Disord. Drug Targets 2015, 14, 378-385. [CrossRef]

72. Tan, L.; Wang, Y.; Jiang, Y.; Wang, R.; Zu, J.; Tan, R. Hydroxysafflor Yellow A Together with Blood-Brain Barrier Regulator Lexiscan for Cerebral Ischemia Reperfusion Injury Treatment. ACS Omega 2020, 5, 19151-19164. [CrossRef]

73. Pak, R.W.; Kang, J.; Valentine, H.; Loew, L.M.; Thorek, D.L.J.; Boctor, E.M.; Wong, D.F.; Kang, J.U. Voltage-sensitive dye delivery through the blood brain barrier using adenosine receptor agonist regadenoson. Biomed. Opt. Express 2018, 9, 3915-3922. [CrossRef] [PubMed]

74. Han, L.; Cai, Q.; Tian, D.; Kong, D.K.; Gou, X.; Chen, Z.; Strittmatter, S.M.; Wang, Z.; Sheth, K.N.; Zhou, J. Targeted drug delivery to ischemic stroke via chlorotoxin-anchored, lexiscan-loaded nanoparticles. Nanomed. Nanotechnol. Biol. Med. 2016, 12, 1833-1842. [CrossRef] [PubMed]

75. Watanabe, H.; Kuhne, W.; Schwartz, P.; Piper, H.M. A2-adenosine receptor stimulation increases macromolecule permeability of coronary endothelial cells. Am. J. Physiol. 1992, 262, H1174-H1181. [CrossRef]

76. Bonetti, P.O.; Wilson, S.H.; Rodriguez-Porcel, M.; Holmes, D.R., Jr.; Lerman, L.O.; Lerman, A. Simvastatin preserves myocardial perfusion and coronary microvascular permeability in experimental hypercholesterolemia independent of lipid lowering. J. Am. Coll. Cardiol. 2002, 40, 546-554. [CrossRef]

77. Di, N.P.; Di, C.A.; Taccardi, A.A.; Di, M.M.; Statile, D.; Maggi, A.; Giuliani, P.; Di, I.P.; Barsotti, A. Effect of A 1 adenosine receptor blockade on postischemic damage to the coronary microcirculation. Cardiologia 1998, 43, 387-393. 
78. Gündüz, D.; Aslam, M.; Krieger, U.; Becker, L.; Grebe, M.; Arshad, M.; Sedding, D.G.; Härtel, F.V.; Abdallah, Y.; Piper, H.M.; et al. Opposing effects of ATP and adenosine on barrier function of rat coronary microvasculature. J. Mol. Cell. Cardiol. 2012, 52, 962-970. [CrossRef] [PubMed]

79. Bindewald, K.; Gündüz, D.; Härtel, F.; Peters, S.C.; Rodewald, C.; Nau, S.; Schäfer, M.; Neumann, J.; Piper, H.M.; Noll, T. Opposite effect of cAMP signaling in endothelial barriers of different origin. Am. J. Physiol. Cell Physiol. 2004, 287, C1246-C1255. [CrossRef]

80. Aslam, M.; Gündüz, D.; Schuler, D.; Li, L.; Sharifpanah, F.; Sedding, D.; Piper, H.M.; Noll, T. Intermedin induces loss of coronary microvascular endothelial barrier via derangement of actin cytoskeleton: Role of RhoA and Rac1. Cardiovasc. Res. 2011, 92, 276-286. [CrossRef]

81. Aslam, M.; Hartel, F.V.; Arshad, M.; Gunduz, D.; Abdallah, Y.; Sauer, H.; Piper, H.M.; Noll, T. cAMP/PKA antagonizes thrombin-induced inactivation of endothelial myosin light chain phosphatase: Role of CPI-17. Cardiovasc. Res. 2010, 87, 375-384. [PubMed]

82. Aslam, M.; Tanislav, C.; Troidl, C.; Schulz, R.; Hamm, C.; Gunduz, D. cAMP controls the restoration of endothelial barrier function after thrombin-induced hyperpermeability via Rac1 activation. Physiol. Rep. 2014, 2, e12175. [CrossRef] [PubMed]

83. Haselton, F.R.; Alexander, J.S.; Mueller, S.N. Adenosine decreases permeability of in vitro endothelial monolayers. J. Appl. Physiol. 1993, 74, 1581-1590. [CrossRef] [PubMed]

84. Gündüz, D.; Tanislav, C.; Schluter, K.D.; Schulz, R.; Hamm, C.; Aslam, M. Effect of ticagrelor on endothelial calcium signalling and barrier function. Thromb. Haemost. 2017, 117, 371-381. [CrossRef]

85. Umapathy, S.N.; Kaczmarek, E.; Fatteh, N.; Burns, N.; Lucas, R.; Stenmark, K.R.; Verin, A.D.; Gerasimovskaya, E.V. Adenosine A 1 receptors promote vasa vasorum endothelial cell barrier integrity via Gi and Akt-dependent actin cytoskeleton remodeling. PLoS ONE 2013, 8, e59733.

86. Capell, B.C.; Olive, M.; Erdos, M.R.; Cao, K.; Faddah, D.A.; Tavarez, U.L.; Conneely, K.N.; Qu, X.; San, H.; Ganesh, S.K.; et al. A farnesyltransferase inhibitor prevents both the onset and late progression of cardiovascular disease in a progeria mouse model. Proc. Natl. Acad. Sci. USA 2008, 105, 15902-15907.

87. Ozaki, T.; Muramatsu, R.; Sasai, M.; Yamamoto, M.; Kubota, Y.; Fujinaka, T.; Yoshimine, T.; Yamashita, T. The P2X4 receptor is required for neuroprotection via ischemic preconditioning. Sci. Rep. 2016, 6, 25893.

88. Zhao, H.; Zhang, X.; Dai, Z.; Feng, Y.; Li, Q.; Zhang, J.H.; Liu, X.; Chen, Y.; Feng, H. P2X7 Receptor Suppression Preserves Blood-Brain Barrier through Inhibiting RhoA Activation after Experimental Intracerebral Hemorrhage in Rats. Sci. Rep. 2016, 6, 23286.

89. Kimbler, D.E.; Shields, J.; Yanasak, N.; Vender, J.R.; Dhandapani, K.M. Activation of P2X7 promotes cerebral edema and neurological injury after traumatic brain injury in mice. PLoS ONE 2012, 7, e41229.

90. Kaiser, M.; Penk, A.; Franke, H.; Krugel, U.; Norenberg, W.; Huster, D.; Schaefer, M. Lack of functional P2X7 receptor aggravates brain edema development after middle cerebral artery occlusion. Purinergic Signal. 2016, 12, 453-463. [CrossRef]

91. Hechler, B.; Freund, M.; Ravanat, C.; Magnenat, S.; Cazenave, J.P.; Gachet, C. Reduced atherosclerotic lesions in P2Y / apolipoprotein E double-knockout mice: The contribution of non-hematopoietic-derived P2Y $\mathrm{Y}_{1}$ receptors. Circulation 2008, 118, 754-763. [CrossRef]

92. Talley Watts, L.; Sprague, S.; Zheng, W.; Garling, R.J.; Jimenez, D.; Digicaylioglu, M.; Lechleiter, J. Purinergic 2 Y1 receptor stimulation decreases cerebral edema and reactive gliosis in a traumatic brain injury model. J. Neurotrauma 2013, 30, 55-66. [CrossRef] [PubMed]

93. Chen, X.; Qian, S.; Hoggatt, A.; Tang, H.; Hacker, T.A.; Obukhov, A.G.; Herring, P.B.; Seye, C.I. Endothelial Cell-Specific Deletion of P2 $\mathrm{Y}_{2}$ Receptor Promotes Plaque Stability in Atherosclerosis-Susceptible ApoE-Null Mice. Arter. Thromb. Vasc. Biol. 2017, 37, 75-83. [CrossRef] [PubMed]

94. Horckmans, M.; Esfahani, H.; Beauloye, C.; Clouet, S.; di Pietrantonio, L.; Robaye, B.; Balligand, J.L.; Boeynaems, J.M.; Dessy, C.; Communi, D. Loss of mouse $\mathrm{P}_{2} \mathrm{Y}_{4}$ nucleotide receptor protects against myocardial infarction through endothelin-1 downregulation. J. Immunol. 2015, 194, 1874-1881. [CrossRef] [PubMed]

95. Stachon, P.; Peikert, A.; Michel, N.A.; Hergeth, S.; Marchini, T.; Wolf, D.; Dufner, B.; Hoppe, N.; Ayata, C.K.; Grimm, M.; et al. P2Y 6 deficiency limits vascular inflammation and atherosclerosis in mice. Arter. Thromb. Vasc. Biol. 2014, 34, 2237-2245. [CrossRef] [PubMed]

96. Barrera, N.P.; Ormond, S.J.; Henderson, R.M.; Murrell-Lagnado, R.D.; Edwardson, J.M. Atomic force microscopy imaging demonstrates that $\mathrm{P} 2 \mathrm{X} 2$ receptors are trimers but that $\mathrm{P} 2 \mathrm{X} 6$ receptor subunits do not oligomerize. J. Biol. Chem. 2005, 280, 10759-10765. [CrossRef] [PubMed]

97. Jiang, L.H.; Kim, M.; Spelta, V.; Bo, X.; Surprenant, A.; North, R.A. Subunit arrangement in P2X receptors. J. Neurosci. 2003, 23, 8903-8910. [CrossRef] [PubMed]

98. Kawate, T.; Michel, J.C.; Birdsong, W.T.; Gouaux, E. Crystal structure of the ATP-gated P2X $\mathrm{X}_{4}$ ion channel in the closed state. Nature 2009, 460, 592-598. [CrossRef]

99. Nicke, A.; Baumert, H.G.; Rettinger, J.; Eichele, A.; Lambrecht, G.; Mutschler, E.; Schmalzing, G. P2X1 and P2X3 receptors form stable trimers: A novel structural motif of ligand-gated ion channels. EMBO J. 1998, 17, 3016-3028. [CrossRef]

100. Glass, R.; Loesch, A.; Bodin, P.; Burnstock, G. P2X4 and P2X6 receptors associate with VE-cadherin in human endothelial cells. Cell. Mol. Life Sci. 2002, 59, 870-881. [CrossRef] [PubMed] 
101. Loesch, A.; Burnstock, G. Ultrastructural localisation of ATP-gated P2X2 receptor immunoreactivity in vascular endothelial cells in rat brain. Endothelium 2000, 7, 93-98. [CrossRef] [PubMed]

102. Glass, R.; Bardini, M.; Robson, T.; Burnstock, G. Expression of nucleotide P2X receptor subtypes during spermatogenesis in the adult rat testis. Cells Tissues Organs 2001, 169, 377-387. [CrossRef]

103. Glass, R.; Burnstock, G. Immunohistochemical identification of cells expressing ATP-gated cation channels (P2X receptors) in the adult rat thyroid. J. Anat. 2001, 198, 569-579. [CrossRef] [PubMed]

104. Lyubchenko, T.; Woodward, H.; Veo, K.D.; Burns, N.; Nijmeh, H.; Liubchenko, G.A.; Stenmark, K.R.; Gerasimovskaya, E.V. $\mathrm{P}_{2} \mathrm{Y}_{1}$ and $\mathrm{P}_{2} \mathrm{Y}_{13}$ purinergic receptors mediate $\mathrm{Ca}^{2+}$ signaling and proliferative responses in pulmonary artery vasa vasorum endothelial cells. Am. J. Physiol. Cell Physiol. 2011, 300, C266-C275. [CrossRef] [PubMed]

105. Menzies, R.I.; Unwin, R.J.; Dash, R.K.; Beard, D.A.; Cowley, A.W., Jr.; Carlson, B.E.; Mullins, J.J.; Bailey, M.A. Effect of P2X4 and P2X7 receptor antagonism on the pressure diuresis relationship in rats. Front. Physiol. 2013, 4, 305. [CrossRef] [PubMed]

106. Ramirez, A.N.; Kunze, D.L. P2X purinergic receptor channel expression and function in bovine aortic endothelium. Am. J. Physiol. Heart Circ. Physiol. 2002, 282, H2106-H2116. [CrossRef]

107. Wilson, H.L.; Varcoe, R.W.; Stokes, L.; Holland, K.L.; Francis, S.E.; Dower, S.K.; Surprenant, A.; Crossman, D.C. P2X receptor characterization and IL-1/IL-1Ra release from human endothelial cells. Br. J. Pharmacol. 2007, 151, 115-127. [CrossRef]

108. Schwiebert, L.M.; Rice, W.C.; Kudlow, B.A.; Taylor, A.L.; Schwiebert, E.M. Extracellular ATP signaling and P2X nucleotide receptors in monolayers of primary human vascular endothelial cells. Am. J. Physiol. Cell. Physiol. 2002, 282, C289-C301. [CrossRef] [PubMed]

109. Ray, F.R.; Huang, W.; Slater, M.; Barden, J.A. Purinergic receptor distribution in endothelial cells in blood vessels: A basis for selection of coronary artery grafts. Atherosclerosis 2002, 162, 55-61. [CrossRef]

110. Yamamoto, K.; Korenaga, R.; Kamiya, A.; Ando, J. Fluid shear stress activates $\mathrm{Ca}^{2+}$ influx into human endothelial cells via P2X4 purinoceptors. Circ. Res. 2000, 87, 385-391. [CrossRef]

111. Sathanoori, R.; Rosi, F.; Gu, B.J.; Wiley, J.S.; Müller, C.E.; Olde, B.; Erlinge, D. Shear stress modulates endothelial KLF2 through activation of P2X4. Purinergic Signal. 2015, 11, 139-153. [CrossRef] [PubMed]

112. Yamamoto, K.; Sokabe, T.; Matsumoto, T.; Yoshimura, K.; Shibata, M.; Ohura, N.; Fukuda, T.; Sato, T.; Sekine, K.; Kato, S.; et al Impaired flow-dependent control of vascular tone and remodeling in P2X4-deficient mice. Nat. Med. 2006, 12, 133-137. [PubMed]

113. Stokes, L.; Scurrah, K.; Ellis, J.A.; Cromer, B.A.; Skarratt, K.K.; Gu, B.J.; Harrap, S.B.; Wiley, J.S. A loss-of-function polymorphism in the human P2X4 receptor is associated with increased pulse pressure. Hypertension 2011, 58, 1086-1092. [CrossRef]

114. Yang, R.; Beqiri, D.; Shen, J.B.; Redden, J.M.; Dodge-Kafka, K.; Jacobson, K.A.; Liang, B.T. P2X4 receptor-eNOS signaling pathway in cardiac myocytes as a novel protective mechanism in heart failure. Comput. Struct. Biotechnol. J. 2015, 13, 1-7. [CrossRef]

115. Pulvirenti, T.J.; Yin, J.L.; Chaufour, X.; McLachlan, C.; Hambly, B.D.; Bennett, M.R.; Barden, J.A. P2X (purinergic) receptor redistribution in rabbit aorta following injury to endothelial cells and cholesterol feeding. J. Neurocytol. 2000, $29,623-631$. [CrossRef]

116. Sathanoori, R.; Sward, K.; Olde, B.; Erlinge, D. The ATP Receptors P2X7 and P2X4 Modulate High Glucose and Palmitate-Induced Inflammatory Responses in Endothelial Cells. PLoS ONE 2015, 10, e0125111.

117. Yang, F.; Zhao, K.; Zhang, X.; Zhang, J.; Xu, B. ATP Induces Disruption of Tight Junction Proteins via IL-1 Beta-Dependent MMP-9 Activation of Human Blood-Brain Barrier In Vitro. Neural Plast. 2016, 2016, 8928530. [CrossRef]

118. Platania, C.B.M.; Lazzara, F.; Fidilio, A.; Fresta, C.G.; Conti, F.; Giurdanella, G.; Leggio, G.M.; Salomone, S.; Drago, F.; Bucolo, C. Blood-retinal barrier protection against high glucose damage: The role of P2X7 receptor. Biochem. Pharmacol. 2019, 168, 249-258. [CrossRef]

119. Galam, L.; Rajan, A.; Failla, A.; Soundararajan, R.; Lockey, R.F.; Kolliputi, N. Deletion of P2X7 attenuates hyperoxia-induced acute lung injury via inflammasome suppression. Am. J. Physiol. Lung Cell. Mol. Physiol. 2016, 310, L572-L581. [CrossRef]

120. Burnstock, G.; Kennedy, C. Is there a basis for distinguishing two types of P2-purinoceptor? Gen. Pharmacol. 1985, 16, 433-440. [CrossRef]

121. Ralevic, V.; Burnstock, G. Receptors for purines and pyrimidines. Pharmacol. Rev. 1998, 50, 413-492.

122. Von Kügelgen, I.; Wetter, A. Molecular pharmacology of P2Y-receptors. Naunyn-Schmiedeberg's Arch. Pharmacol. 2000, 362, 310-323. [CrossRef]

123. Abbracchio, M.P.; Burnstock, G.; Boeynaems, J.M.; Barnard, E.A.; Boyer, J.L.; Kennedy, C.; Knight, G.E.; Fumagalli, M.; Gachet, C.; Jacobson, K.A.; et al. International Union of Pharmacology LVIII: Update on the P2Y G protein-coupled nucleotide receptors: From molecular mechanisms and pathophysiology to therapy. Pharmacol. Rev. 2006, 58, 281-341. [CrossRef]

124. Kennedy, C. P2Y 11 Receptors: Properties, Distribution and Functions. Adv. Exp. Med. Biol. 2017, 1051, $107-122$.

125. Von Kügelgen, I. Structure, Pharmacology and Roles in Physiology of the P2Y $\mathrm{Y}_{12}$ Receptor. Adv. Exp. Med. Biol. 2017, 1051, 123-138.

126. Perez-Sen, R.; Gomez-Villafuertes, R.; Ortega, F.; Gualix, J.; Delicado, E.G.; Miras-Portugal, M.T. An Update on P2Y13 Receptor Signalling and Function. Adv. Exp. Med. Biol. 2017, 1051, 139-168.

127. Müller, C.E.; Baqi, Y.; Namasivayam, V. Agonists and Antagonists for Purinergic Receptors. Methods Mol. Biol. 2020, $2041,45-64$.

128. Jacobson, K.A.; Delicado, E.G.; Gachet, C.; Kennedy, C.; von Kugelgen, I.; Li, B.; Miras-Portugal, M.T.; Novak, I.; Schoneberg, T.; Perez-Sen, R.; et al. Update of P2Y receptor pharmacology: IUPHAR Review 27. Br. J. Pharmacol. 2020, 177, 2413-2433. [CrossRef] 
129. Prada, M.P.; Syed, A.U.; Buonarati, O.R.; Reddy, G.R.; Nystoriak, M.A.; Ghosh, D.; Simo, S.; Sato, D.; Sasse, K.C.; Ward, S.M.; et al. A Gs-coupled purinergic receptor boosts $\mathrm{Ca}^{2+}$ influx and vascular contractility during diabetic hyperglycemia. eLife 2019, 8, e42214. [CrossRef]

130. Miras-Portugal, M.T.; Queipo, M.J.; Gil-Redondo, J.C.; Ortega, F.; Gomez-Villafuertes, R.; Gualix, J.; Delicado, E.G.; Perez-Sen, R. P2 receptor interaction and signalling cascades in neuroprotection. Brain Res. Bull. 2019, 151, 74-83. [CrossRef]

131. Hechler, B.; Vigne, P.; Leon, C.; Breittmayer, J.P.; Gachet, C.; Frelin, C. ATP derivatives are antagonists of the P2Y 1 receptor: Similarities to the platelet ADP receptor. Mol. Pharmacol. 1998, 53, 727-733. [CrossRef]

132. Aslam, M.; Sedding, D.; Koshty, A.; Santoso, S.; Schulz, R.; Hamm, C.; Gündüz, D. Nucleoside triphosphates inhibit ADP, collagen, and epinephrine-induced platelet aggregation: Role of $\mathrm{P}_{2} \mathrm{Y}_{1}$ and $\mathrm{P} 2 \mathrm{Y}_{12}$ receptors. Thromb. Res. 2013, 132, 548-557. [CrossRef]

133. Fabre, J.E.; Nguyen, M.; Latour, A.; Keifer, J.A.; Audoly, L.P.; Coffman, T.M.; Koller, B.H. Decreased platelet aggregation, increased

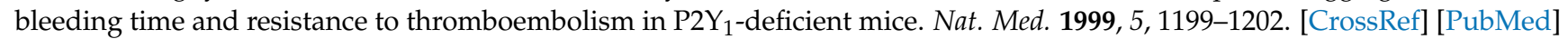

134. Geary, C.; Akinbi, H.; Korfhagen, T.; Fabre, J.E.; Boucher, R.; Rice, W. Increased susceptibility of purinergic receptor-deficient mice to lung infection with Pseudomonas aeruginosa. Am. J. Physiol. Lung Cell. Mol. Physiol. 2005, 289, L890-L895. [CrossRef]

135. Zerr, M.; Hechler, B.; Freund, M.; Magnenat, S.; Lanois, I.; Cazenave, J.P.; Leon, C.; Gachet, C. Major contribution of the $\mathrm{P} 2 \mathrm{Y}_{1}$ receptor in purinergic regulation of TNFalpha-induced vascular inflammation. Circulation 2011, 123, 2404-2413. [CrossRef]

136. Soulet, C.; Hechler, B.; Gratacap, M.P.; Plantavid, M.; Offermanns, S.; Gachet, C.; Payrastre, B. A differential role of the platelet ADP receptors $\mathrm{P}_{2} \mathrm{Y}_{1}$ and $\mathrm{P} 2 \mathrm{Y}_{12}$ in Rac activation. J. Thromb. Haemost. 2005, 3, 2296-2306. [CrossRef]

137. Wang, S.; Iring, A.; Strilic, B.; Albarran Juarez, J.; Kaur, H.; Troidl, K.; Tonack, S.; Burbiel, J.C.; Müller, C.E.; Fleming, I.; et al. P2 $Y_{2}$ and $G_{q} / G_{11}$ control blood pressure by mediating endothelial mechanotransduction. J. Clin. Investig. 2015, 125, 3077-3086. [CrossRef]

138. Agca, Y.; Qian, S.; Agca, C.; Seye, C.I. Direct Evidence for $\mathrm{P} 2 \mathrm{Y}_{2}$ Receptor Involvement in Vascular Response to Injury. J. Vasc. Res. 2016, 53, 163-171. [CrossRef]

139. Kukulski, F.; Ben Yebdri, F.; Bahrami, F.; Fausther, M.; Tremblay, A.; Sevigny, J. Endothelial P2Y 2 receptor regulates LPS-induced neutrophil transendothelial migration in vitro. Mol. Immunol. 2010, 47, 991-999. [CrossRef]

140. Horckmans, M.; Robaye, B.; Leon-Gomicronmez, E.; Lantz, N.; Unger, P.; Dol-Gleizes, F.; Clouet, S.; Cammarata, D.; Schaeffer, P.; Savi, P.; et al. P2 $\mathrm{Y}_{4}$ nucleotide receptor: A novel actor in post-natal cardiac development. Angiogenesis 2012, 15, 349-360. [CrossRef]

141. Bar, I.; Guns, P.J.; Metallo, J.; Cammarata, D.; Wilkin, F.; Boeynams, J.M.; Bult, H.; Robaye, B. Knockout mice reveal a role for ${\mathrm{P} 2 \mathrm{Y}_{6}}_{6}$ receptor in macrophages, endothelial cells, and vascular smooth muscle cells. Mol. Pharmacol. 2008, 74, 777-784. [CrossRef] [PubMed]

142. Anwar, Z.; Albert, J.L.; Gubby, S.E.; Boyle, J.P.; Roberts, J.A.; Webb, T.E.; Boarder, M.R. Regulation of cyclic AMP by extracellular ATP in cultured brain capillary endothelial cells. Br. J. Pharmacol. 1999, 128, 465-471. [CrossRef] [PubMed]

143. Clouet, S.; Di Pietrantonio, L.; Daskalopoulos, E.P.; Esfahani, H.; Horckmans, M.; Vanorle, M.; Lemaire, A.; Balligand, J.L.; Beauloye, C.; Boeynaems, J.M.; et al. Loss of Mouse P2Y 6 Nucleotide Receptor Is Associated with Physiological Macrocardia and Amplified Pathological Cardiac Hypertrophy. J. Biol. Chem. 2016, 291, 15841-15852. [CrossRef] [PubMed]

144. Garcia, R.A.; Yan, M.; Search, D.; Zhang, R.; Carson, N.L.; Ryan, C.S.; Smith-Monroy, C.; Zheng, J.; Chen, J.; Kong, Y.; et al. $\mathrm{P}_{2} \mathrm{Y}_{6}$ receptor potentiates pro-inflammatory responses in macrophages and exhibits differential roles in atherosclerotic lesion development. PLoS ONE 2014, 9, e111385.

145. Wen, R.X.; Shen, H.; Huang, S.X.; Wang, L.P.; Li, Z.W.; Peng, P.; Mamtilahun, M.; Tang, Y.H.; Shen, F.X.; Tian, H.L.; et al. P2Y 6 receptor inhibition aggravates ischemic brain injury by reducing microglial phagocytosis. CNS Neurosci. Ther. 2020, 26, 416-429. [CrossRef]

146. Dreisig, K.; Kornum, B.R. A critical look at the function of the P2Y 11 receptor. Purinergic Signal. 2016, 12, 427-437.

147. Casieri, V.; Matteucci, M.; Pasanisi, E.M.; Papa, A.; Barile, L.; Fritsche-Danielson, R.; Lionetti, V. Ticagrelor Enhances Release of Anti-Hypoxic Cardiac Progenitor Cell-Derived Exosomes Through Increasing Cell Proliferation In Vitro. Sci. Rep. 2020, 10, 2494.

148. Uehara, K.; Uehara, A. P2 $\mathrm{Y}_{1}, \mathrm{P}_{2} \mathrm{Y}_{6}$, and $\mathrm{P} 2 \mathrm{Y}_{12}$ receptors in rat splenic sinus endothelial cells: An immunohistochemical and ultrastructural study. Histochem. Cell Biol. 2011, 136, 557-567. [CrossRef]

149. Li, F.; Li, W.; Li, X.; Li, F.; Zhang, L.; Wang, B.; Huang, G.; Guo, X.; Wan, L.; Liu, Y.; et al. Geniposide attenuates inflammatory response by suppressing $\mathrm{P}_{2} \mathrm{Y}_{14}$ receptor and downstream ERK1/2 signaling pathway in oxygen and glucose deprivation-induced brain microvascular endothelial cells. J. Ethnopharmacol. 2016, 185, 77-86. [CrossRef]

150. Alsaqati, M.; Latif, M.L.; Chan, S.L.; Ralevic, V. Novel vasocontractile role of the $\mathrm{P}_{2} \mathrm{Y}_{14}$ receptor: Characterization of its signalling in porcine isolated pancreatic arteries. Br. J. Pharmacol. 2014, 171, 701-713. [CrossRef]

151. Relja, B.; Land, W.G. Damage-associated molecular patterns in trauma. Eur. J. Trauma Emerg. Surg. 2020, 46, 751-775. [CrossRef] [PubMed] 